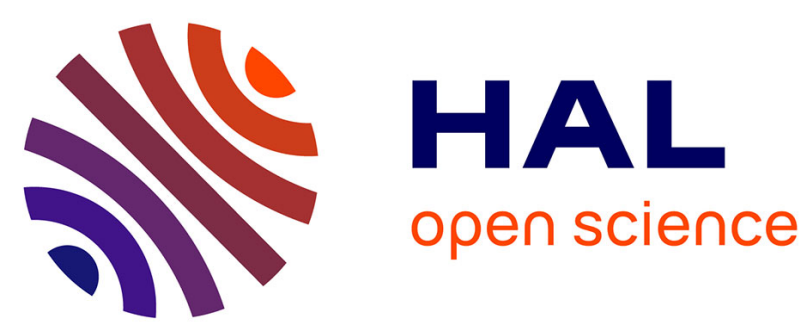

\title{
Deformation behavior of continental crust during subduction and exhumation: Strain distribution over the Tenda massif (Alpine Corsica, France)
}

\author{
Alexandre Beaudoin, Romain Augier, Laurent Jolivet, Anthony Jourdon, \\ Hugues Raimbourg, Stéphane Scaillet, Giovanni Luca Cardello
}

\section{To cite this version:}

Alexandre Beaudoin, Romain Augier, Laurent Jolivet, Anthony Jourdon, Hugues Raimbourg, et al.. Deformation behavior of continental crust during subduction and exhumation: Strain distribution over the Tenda massif (Alpine Corsica, France). Tectonophysics, 2017, 705, pp.12-32. 10.1016/j.tecto.2017.03.023 . insu-01502958

\section{HAL Id: insu-01502958 \\ https://hal-insu.archives-ouvertes.fr/insu-01502958}

Submitted on 8 Apr 2017

HAL is a multi-disciplinary open access archive for the deposit and dissemination of scientific research documents, whether they are published or not. The documents may come from teaching and research institutions in France or abroad, or from public or private research centers.
L'archive ouverte pluridisciplinaire HAL, est destinée au dépôt et à la diffusion de documents scientifiques de niveau recherche, publiés ou non, émanant des établissements d'enseignement et de recherche français ou étrangers, des laboratoires publics ou privés.

\section{(ㅇ)(1) $\$$}

Distributed under a Creative Commons Attribution - NonCommercial - NoDerivatives 44.0 


\section{Accepted Manuscript}

Deformation behavior of continental crust during subduction and TEGTONOPHYSICS

exhumation: Strain distribution over the Tenda massif (Alpine

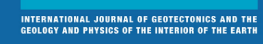

Corsica, France)

Alexandre Beaudoin, Romain Augier, Laurent Jolivet, Anthony Jourdon, Hugues Raimbourg, Stéphane Scaillet, Giovanni Luca Cardello

PII: $\quad$ S0040-1951(17)30122-1

DOI: $\quad$ doi: $10.1016 /$ j.tecto.2017.03.023

Reference: $\quad$ TECTO 127440

To appear in: $\quad$ Tectonophysics

Received date: $\quad 4$ May 2016

Revised date: $\quad 6$ March 2017

Accepted date: $\quad 24$ March 2017

Please cite this article as: Alexandre Beaudoin, Romain Augier, Laurent Jolivet, Anthony Jourdon, Hugues Raimbourg, Stéphane Scaillet, Giovanni Luca Cardello, Deformation behavior of continental crust during subduction and exhumation: Strain distribution over the Tenda massif (Alpine Corsica, France). The address for the corresponding author was captured as affiliation for all authors. Please check if appropriate. Tecto(2017), doi: 10.1016/j.tecto.2017.03.023

This is a PDF file of an unedited manuscript that has been accepted for publication. As a service to our customers we are providing this early version of the manuscript. The manuscript will undergo copyediting, typesetting, and review of the resulting proof before it is published in its final form. Please note that during the production process errors may be discovered which could affect the content, and all legal disclaimers that apply to the journal pertain. 
1 Deformation behavior of continental crust during subduction and exhumation: Strain

2 distribution over the Tenda massif (Alpine Corsica, France)

3

4 Alexandre Beaudoin ${ }^{\mathrm{a}, \mathrm{b}, \mathrm{c},{ }^{*}}$, Romain Augier ${ }^{\mathrm{a}, \mathrm{b}, \mathrm{c}}$, Laurent Jolivet ${ }^{\mathrm{a}, \mathrm{b}, \mathrm{c}}$, Anthony Jourdon ${ }^{\mathrm{d}}$, Hugues

$5 \quad$ Raimbourg $^{\mathrm{a}, \mathrm{b}, \mathrm{c}}$, Stéphane Scaillet ${ }^{\mathrm{a}, \mathrm{b}, \mathrm{c}}$, Giovanni Luca Cardello ${ }^{\mathrm{e}}$.

6

$7 \quad{ }^{a}$ Université d'Orléans, ISTO, UMR 7327, 45071, Orléans, France

$8 \quad{ }^{\mathrm{b}} \mathrm{CNRS} / \mathrm{INSU}$, ISTO, UMR 7327, 45071, Orléans, France

$9 \quad{ }^{\mathrm{c}}$ BRGM, ISTO, UMR 7327, 45060, Orléans, France

10 déoazur, UMR 7329, 06560, Valbonne, France

$11{ }^{\mathrm{e}}$ Section des sciences de la Terre et de l'environnement, Université de Genève

13 * Corresponding author: Alexandre Beaudoin, ISTO, 1A rue de la Férollerie, 45071, Orléans,

14 France (e-mail: alexandre.beaudoin@univ-orleans.fr; Tel: +33 2384925 73)

Abstract

17

In order to address the question of strain localization within continental units during subduction and exhumation, a large-scale portion of an exhumed continental crust was structurally revisited. The Tenda massif (Alpine Corsica) has recorded burial ( $\mathrm{D}_{1}$; top-to-theSW kinematics) down to blueschist-facies conditions followed by exhumation $\left(\mathrm{D}_{2}\right.$; top-to-theNE kinematics). It was so far regarded as a quite rigid unit with strain localization at the upper contact with the overlying oceanic material, the East Tenda Shear Zone (ETSZ), where previous studies were focused. A structural analysis carried out from the core to the boundaries of this continental unit shows instead that deformation is pervasive in the whole 
section. A reappraisal of the finite structure shows that this unit corresponds to a $\mathrm{N} 140^{\circ} \mathrm{E}$ elongated dome of $\mathrm{D}_{2}$ fabrics severely overprinting earlier $\mathrm{D}_{1}$ structures, locally preserved in the core of the dome. Field observations show that deformation was distributed at maximum burial, pervasively affecting both the Tenda massif and the overlying tectonically coupled oceanic material. Strain remained distributed during the first steps of exhumation that probably started during the last stages of subduction. After a regional switch from compression to extension, deformation localized toward the ETSZ and other internal shear zones such as the newly described Saleccia Shear Zone, as shown by strain intensity mapping in the eastern granitic protoliths. Doming occurred during this localization when crossing the brittle-ductile transition. This large-scale structural study shows that lithological boundaries controlled the place where strain localized, while the general style of deformation (distributed vs localized) was controlled by depth (i.e. pressure-temperature conditions), interacting with other parameters such as fluid circulation and protolith composition.

Key-words: Alpine Corsica; Tenda massif; Continental crust; Exhumation; Shear zone; Strain localization.

\section{Introduction}

The progressive deformation of continental basement units from the thrust front to the internal zones of subduction wedges largely depends upon the rheology of the subducting lithosphere. In particular, the style of deformation near the thrust front is diagnostic of the initial rheological stratification of the foreland domain of orogens (Mouthereau et al., 2013). Although the continental basement is often considered rigid in forelands, the western Alps or the Zagros show thick-skin deformation near the thrust front where both basement rocks and 
cover series experienced significant amounts of shortening along localized shear zones active in the conditions of the greenschist facies (e.g. Leloup et al., 2005; Mouthereau et al., 2007; Bellahsen et al., 2012; Bellanger et al., 2014). In the internal zones of orogens, continental units are intensely deformed and sheared in high-pressure and low-temperature (HP-LT) conditions (blueschists and eclogite facies) during both subduction and exhumation (e.g. Huet et al., 2009). Thus, from the external to the internal zones, deformation is less and less localized mainly because temperature increases, but the evolution of continental units between these two end members is poorly known.

The Tenda massif in Alpine Corsica provides an example of subduction of a continental basement which experienced both intermediate $P-T$ conditions (lower blueschists facies) and strong strain localization along the East Tenda Shear Zone (ETSZ), which was activated during subduction and exhumation (Cohen et al., 1981; Mattauer et al., 1981; Jourdan, 1988; Jolivet et al., 1990; 1991; Daniel et al., 1996; Molli and Tribuzio, 2004; Molli et al., 2006; Maggi et al., 2012; 2014; Rossetti et al., 2015).

The Alpine Corsica HP-LT orogenic wedge includes both Ligurian oceanic and European continental units (e.g. Mattauer et al., 1981; Agard and Vitale-Brovarone, 2013; Vitale-Brovarone et al., 2013). It is part of a larger orogenic system of which the most external zones are the Provence fold-and-thrust belt and the poorly deformed Western Corsica Variscan basement (Lacombe and Jolivet, 2005). The internal parts of the wedge, resting on top of Western Corsica, correspond to a westward-verging stack of nappes characterized by an eastward metamorphic gradient from lower blueschist-facies in the western continental Tenda massif to eclogite-facies conditions in the eastern oceanic Schistes Lustrés nappe (e.g. Mattauer et al., 1981; Lahondère, 1988; Fournier et al., 1991; Caron, 1994; Vitale-Brovarone et al., 2013). Several tectonometamorphic units are superimposed and separated by tectonic contacts and sharp metamorphic gaps (Fournier et al., 1991; Caron, 1994; Malavieille et al., 

1998; Vitale-Brovarone et al., 2013). The Tenda massif represents a part of the continental margin involved in the orogenic wedge. It is regarded as a quite rigid block that escaped significant internal deformation during subduction and exhumation (Mattauer et al., 1981; Daniel et al., 1996; Gueydan et al., 2003; Molli et al., 2006; Maggi et al., 2012; 2014; Rossetti et al., 2015) with shearing mostly localized along its eastern margin, the ETSZ, where most of earlier studies have focused so far. This apparent rigidity resulted in contrasting interpretations regarding strain distribution and exhumation mechanisms. Although this major structure has probably accommodated a significant part of the finite deformation, the internal deformation and its evolution toward the ETSZ have never been fully described.

In this study, we reviewed the style, magnitude, and significance of deformation of the entire Tenda massif based on a new and extensive structural characterization. Finite strain markers relative to burial and exhumation were identified, mapped and characterized across a large portion of this continental unit. A scale of relative strain intensity and partitioning in the eastern granitic complex of the Tenda massif was built with the aim to reconstruct a succession of superimposed structures in a continuum of deformation. Thus, a new high resolution map of the intensity of deformation is here presented, having implications on strain distribution, strain localization factors and exhumation processes during the whole subduction/exhumation story.

\section{Geological setting}

\subsection{Alpine Corsica}

Corsica is divided in two geological domains: Variscan Corsica in the west and Alpine Corsica in the northeast (Durand-Delga, 1984) (Fig. 1). Alpine Corsica consists of a stack of 
variably metamorphosed tectonic units belonging to a HP-LT subduction complex (e.g.

102 Mattauer et al., 1981; Lahondère, 1988; Fournier, 1991; Caron, 1994; Vitale Brovarone et al.,

103 2013). Formerly attached to the European continent, Corsica and Sardinia have migrated

104 during the rifting of the Liguro-Provençal basin to reach their current position in Oligocene-

105 Miocene times (e.g. Réhault et al., 1984; Speranza et al., 2002; Ferrandini et al., 2003;

106 Maffione et al., 2008). Although multiple tectonometamorphic units can be distinguished (e.g.

107 Vitale Brovarone et al., 2013), Alpine Corsica is conventionally divided into three major 108 groups of units, from bottom to top: 1 - the external continental units, including the Tenda

109 massif; 2 - the Schistes Lustrés nappe; and 3 - the Nappes Supérieures (Durand-Delga, 1984;

110 Jolivet et al., 1990; Malavieille et al., 1998; Molli, 2008) (Fig. 1).

111 The external continental units correspond to autochthonous or parautochthonous units

112 that were involved in Alpine subduction under greenschists to lower blueschists-facies 113 conditions for the Sampolo and Popolasca units (Malasoma et al., 2006; Malasoma and

114 Marroni, 2007; Garfagnoli et al., 2009; Vitale Brovarone et al., 2013; Di Rosa et al., 2016) up

115 to middle-grade blueschists-facies conditions for the Tenda massif (Gibbons and Horak, 1984;

116 Tribuzio and Giacomini, 2002; Molli and Tribuzio, 2004; Maggi et al., 2012; Vitale

117 Brovarone et al., 2013).

118 The Schistes Lustrés nappe is mainly composed of more or less coherent pieces of

119 metabasites, metasediments of oceanic affinity and few subordinate continental units (Centuri 120 and Serra di Pigno units). These continental slices were incorporated in the Schistes Lustrés 121 complex during the Alpine subduction (Faure and Malavieille, 1981), or prior to subduction, 122 as extensional allochthons, in an Ocean-Continental Transition zone (OCT) (Lahondère and 123 Guerrot, 1997; Martin et al., 2011; Vitale Brovarone et al., 2011a; Meresse et al., 2012). The

124 Schistes Lustrés nappe was deeply buried during subduction as evidenced by the widespread 125 occurrences of blueschist- and eclogite-facies assemblages present in both internal continental 
units and metabasites (Caron et al., 1981; Caron and Péquignot, 1986; Lahondère, 1988;

127 Fournier et al., 1991; Caron, 1994; Jolivet et al., 1998; Ravna et al., 2010; Vitale Brovarone et al., 2011a; 2011b).

The Nappes Supérieures (Balagne, Nebbio, Macinaggio, Pineto and Inzecca units) essentially consist of ophiolites of Jurassic age and Cretaceous flyschs of Ligurian affinity (Beccaluva et al., 1981; Ohnenstetter et al., 1981; De Wever et al., 1987) of low metamorphic grade (i.e. $\mathrm{T}_{\max }=300{ }^{\circ} \mathrm{C}$, Vitale Brovarone et al., 2013).

These nappes are overthrust on the autochthonous crystalline basement of Variscan

134 Corsica and Eocene foreland deposits (Fig. 1) ensuring a Bartonian biostratigraphic constraint on the timing of Alpine deformation at the front of the belt (Bonnal et al., 1973; Bézert and Caby, 1988; Jourdan, 1988; Egal and Caron, 1989; Vitale Brovarone et al., 2013). HP-LT metamorphism in the Schistes Lustrés nappe yielded scattered ages spanning from controversial Late Cretaceous ages (Sm-Nd on whole-rock, garnet, jadeite and glaucophane,

139 Lahondère and Guerrot, $1997 ;{ }^{40} \mathrm{Ar} /{ }^{39} \mathrm{Ar}$ on glaucophane, Maluski, 1977) to Late Eocene ages

$140 \quad\left({ }^{40} \mathrm{Ar} /{ }^{39} \mathrm{Ar}\right.$ on phengite, Brunet et al., 2000; U-Pb on zircon, Martin et al., 2011; Lu-Hf on

141 Garnet; Vitale Brovarone and Herwartz, 2013). HP-LT rocks from the Tenda massif yielded

142 almost similar ages from $54 \pm 8 \mathrm{Ma}$ (U-Pb on acmite-phengite assemblages, Maggi et al.,

143 2012) and $\sim 36 \mathrm{Ma}\left({ }^{40} \mathrm{Ar} /{ }^{39} \mathrm{Ar}\right.$ on phengite, Brunet et al., 2000). Similar ages (37-33 Ma) were

144 retrieved from the most external Alpine shear zones $\left(\mathrm{T}=300^{\circ} \mathrm{C} ; \mathrm{P}>0.6 \mathrm{GPa}\right)$ affecting the

145 Variscan basement $\left({ }^{40} \mathrm{Ar} /{ }^{39} \mathrm{Ar}\right.$ on phengite; Di Vincenzo et al., 2016).

146 Timing of exhumation and extensional tectonics appears also quite well constrained.

147 Extensional regime is ensured by the development of extensional sedimentary basins that 148 overprinted the structure of the subduction complex, notably the St-Florent basin that 149 developed on top of the Nebbio and the Schistes Lustrés nappe. Activity of the bounding 150 normal faults is ascribed to the syn-tectonic deposition of Burdigalian to Serravallian marine 
sediments (Ferrandini et al., 1998; Cavazza et al., 2007). Besides, the youngest retrogression

152 ages associated to exhumation retrieved from greenschist-facies rocks are well constrained in

153 both the Schistes Lustrés nappe and the Tenda massif between 25 and 20 Ma (Brunet et al.,

154 2000; Rossetti et al., 2015). Final exhumation stages of the internal zones including the Tenda

155 massif as constrained by fission tracks low-temperature thermochronology on both zircon and

156 apatite yielded Late Oligocene to Miocene ages (Jakni et al., 2000; Fellin et al., 2006).

At first glance, the finite structure of Alpine Corsica therefore results from a quite simple two-stepped tectonometamorphic evolution of subduction (burial) and exhumation. The first event corresponds to ductile deformation recorded in $\mathrm{HP}$-LT conditions in both the Schistes Lustrés and Tenda units. This event is associated with a top-to-the-SW shearing

161 localizing toward the contact between the two units that accommodated the thrusting of the

162 Schistes Lustrés nappe over the Tenda massif (Cohen et al., 1981; Faure and Malavieille, 1981; Mattauer et al., 1981; Jourdan, 1988; Molli and Tribuzzio, 2004; Molli et al., 2006). It is followed by a post-HP event including series of top-to-the-E shearing and E-verging folding extensional increments in the Schistes Lustrés nappe (Faure and Malavieille, 1981; Jolivet et al., 1990; 1991; Fournier et al., 1991) and the Tenda massif (Jourdan, 1988; Jolivet

167 et al., 1990; 1991; Daniel et al., 1996; Molli and Tribuzio, 2004; Molli et al., 2006). These 168 late structures were interpreted as reactivating in the opposite direction some early thrusts 169 either as backthrusts (Faure and Malavieille, 1980), or as extensional shear zones (Jolivet et 170 al., 1990; 1991; Fournier et al., 1991; Daniel et al., 1996; Molli and Tribuzio, 2004; Molli et 171 al., 2006; Rossetti et al., 2015). Interpreted as the result of syn-orogenic extension or regional 172 post-orogenic extension, the geodynamic context that prevailed during early stages of 173 exhumation is a matter of debate, leaving interpretation of some first order contacts, such as 174 the ETSZ, controversial (Molli et al., 2006). 
The Tenda massif (Fig. 1) is bounded to the east by the ETSZ that marks the contact with the Schistes Lustrés nappe and to the west by the Ostriconi fault, which instead puts it in contact with the Nappes Supérieures of Balagne (Jourdan, 1988). It consists primarily to a Variscan basement portion overlain by Meso-Cenozoic cover series all involved into Alpine tectono-metamorphic events (Fig. 2). To the west, it is represented by Proterozoic to Paleozoic medium-grade rocks (gneisses and micaschists) unconformably overlain by Late Variscan volcano-sedimentary rocks (Rossi et al., 1994). At variance, the eastern part of the massif is mainly composed of a Late Carboniferous-Early Permian granitic complex (Rossi et al., 1993), intrusive in the volcano-sedimentary rocks. It includes from east to west the Mt

187 Asto monzogranite, directly under the Schistes Lustrés nappe, the Casta granodiorite and the Mt Genova leucomonzogranite, in contact with the volcano-sedimentary and micaschists sequences (Rossi et al., 1994). The Triassic to Eocene sedimentary cover that remains united with the basement is only locally preserved, notably near Santo-Pietro-di-Tenda in the east

191 (Jourdan, 1988; Rossi et al., 2001; Vitale Brovarone et al., 2013).

192 Evidence of the Alpine subduction of the Tenda massif is expressed by both an intense deformation near the ETSZ and the local development of HP-LT index metamorphic associations. They are often limited to celadonite-rich phengite in all types of intrusive rocks, 195 and sodic blue-amphibole (riebeckite-ferroglaucophane), jadeite-bearing aegirine or even 196 clinopyroxene + rutile, in granitoids of peculiar composition (Gibbons and Horak, 1994;

197 Tribuzio and Giacomini, 2002; Molli and Tribuzio, 2004; Molli et al., 2006; Maggi et al., 198 2012; Rossetti et al., 2015). Peak metamorphic conditions estimates fall in the blueschists199 facies conditions in the range of 1-1.2 $\mathrm{GPa}$ and $400-450{ }^{\circ} \mathrm{C}$ (Tribuzio and Giacomini, 2002; 200 Molli and Tribuzio, 2004; Molli et al., 2006; Maggi et al., 2012) confirmed by independent 
temperature estimates retrieved on metasediments from cover series (Vitale Brovarone et al., 2013). Exhumation is marked by an overall pressure decrease inferred from the decrease in Si-content in phengite (Molli et al., 2006; Maggi et al., 2012; Rossetti et al., 2015). An exhumation path was recently recognized from $\sim 1 \mathrm{GPa}$ and $450{ }^{\circ} \mathrm{C}$ to $<0.5 \mathrm{GPa}$ and 300 $400^{\circ} \mathrm{C}$ (Tribuzio and Giacomini, 2002; Molli and Tribuzio, 2004; Molli et al., 2006).

Just as the whole Alpine Corsica, the finite structure of the Tenda massif was achieved through a two-stepped history. All studies agree on a first event, $\mathrm{D}_{1}$, responsible for the development of a first planar-linear fabric (referred as $\mathrm{S}_{1} / \mathrm{L}_{1}$ in this study) accompanied with a top-to-the-SW sense of shear during subduction and burial in blueschists-facies conditions (Cohen et al., 1981; Mattauer et al., 1981; Jourdan, 1988; Daniel et al., 1996; Molli and Tribuzio, 2004; Molli et al., 2006; Molli and Malavieille, 2011; Maggi et al., 2012; 2014; Rossetti et al., 2015). This event corresponds to the underthrusting of the Tenda massif below the Schistes Lustrés nappe. Except for $\mathrm{D}_{1}$, models and history of subduction/exhumation and strain localization of the Tenda massif in the frame of Alpine Corsica can be very different depending on papers. Three models are proposed:

- For Jolivet et al. (1990; 1991), Daniel et al. (1996) and Gueydan et al. (2003), $\mathrm{D}_{1}$ is placed during the Eocene. Then, a post-orogenic exhumation of Alpine Corsica started near $30 \mathrm{Ma}$, with top-to-the-NE deformation localized notably toward the ETSZ that is reworked in greenschist-facies conditions. This $\mathrm{D}_{2}$ phase is associated to folds affecting the former $\mathrm{S}_{1}$, and a crenulation cleavage (referred as $S_{2}$ in this study) preserved in less non-coaxial deformation domains between top-to-the-NE shear zones. A second lineation (referred as $\mathrm{L}_{2}$ in this study) developed on $\mathrm{S}_{2}$ planes. The feldspar-to-phengite reaction is responsible for strain localization near the contact with the Schistes Lustrés nappe (Gueydan et al., 2003). A $\mathrm{D}_{3}$ phase is used in this model for brittle extensional structures in a continuum of deformation during exhumation (Daniel et al., 1996). 
- A more recent model rather considers most of the exhumation syn-orogenic (Molli and Tribuzio, 2004; Molli et al., 2006). The $\mathrm{D}_{1}$ phase is therefore placed earlier, before the Early Eocene and until $40 \mathrm{Ma}$. $\mathrm{S}_{1}$ folding and crenulation cleavage are interpreted occurring in low-strained domains in between zones of localized top-to-the-SW shearing during $\mathrm{D}_{1}$ (Molli et al., 2006; Rossetti et al., 2015). After 40 Ma, during thrusting of the most external 231 continental domains, a first step of syn-convergence exhumation $\left(\mathrm{D}_{2}\right)$ occurred for both the 232 Schistes Lustrés nappe and the Tenda massif until 32 Ma. It is accommodated by a top-tothe-SW shear zone contact below the Tenda massif and a top-to-the-NE shear zone at the top

234 of the Schistes Lustrés nappe (Molli and Tribuzio, 2004; Molli et al., 2006). Associated 235 structures are $\mathrm{D}_{2}$ folds, crenulation and both top-to-the-NE and -SW shear bands formation in 236 the Tenda massif, and penetrative folding in the Schistes Lustrés nappe. The contact between 237 the two units is itself involved in large-scale $D_{2}$ folds, in a general delocalization of strain 238 within the orogenic wedge. The ETSZ is finally reactivated in a post-orogenic context until 239 brittle conditions at the end of the exhumation $\left(D_{3}\right)$. Those final phases of exhumation 240 evolved from the ductile field (top-to-the-NE shearing and folds with axes parallel to the 241 stretching lineation) up to the brittle field, with the development of semi-brittle shear bands 242 and cataclasite-bearing fault zones. - A third model (Maggi et al., 2012; 2014; Rossetti et al., 2015) is in agreement with

244 the timing of events and the syn-orogenic character of exhumation described in the previous 245 model of Molli and Tribuzio (2004) and Molli et al. (2006). However, the ETSZ remained 246 active during exhumation with progressive strain localization from distributed in gneiss lenses 247 to localized in top-to-the-SW shear zones. The ETSZ is characterized by a transient rheology 248 with softening during feldspar-to-micas reaction and hardening by noeblastesis of K-feldspar 249 during fluid metasomatism. The ultimate stage of localization is top-to-the-SW phyllonites, 
which are the only structures reactivated semi-brittlely during post-orogenic extension. In

251 their model, the Tenda massif remains undeformed beneath the ETSZ.

3. Structure and finite strain of the Tenda massif

A field survey was carried out on the whole Tenda massif including a detailed study of structural features and geological mapping in order to complement the map of the French Geological Survey (BRGM; Rossi et al., 1994; 2001). Strain markers were retrieved over

more than 700 measurement stations throughout the massif. In the deformed parts, all metamorphic rocks are often pervasively foliated and generally exhibit a well-defined stretching lineation. Results are projected on the maps of figures 2 (foliations) and 4 261 (stretching lineations with sense of shear) and are illustrated by representative outcrops and cross sections (Figs. 3 and 5), complementing earlier studies focused on the ETSZ (Daniel et al., 1996; Molli and Tribuzio, 2004; Molli et al., 2006; Maggi et al., 2014).

\subsection{Foliations and folds}

At least two planar fabrics, related to $\mathrm{D}_{1}$ and $\mathrm{D}_{2}$, are observed, some forming largescale features apparent in the landscape (Fig. 3). A total of $207 \mathrm{~S}_{1}$ and $482 \mathrm{~S}_{2}$ planes were measured in all lithologies of the Tenda massif and in the Schistes Lustrés nappe close to the contact (Fig. 2a). Both $S_{1}$ and $S_{2}$ are found in almost the whole volume of the massif showing that deformation is not restricted to the ETSZ. $\mathrm{S}_{2}$ commonly dips away from the center of the Tenda massif with trajectories showing a concentric pattern depicting a N140 ${ }^{\circ}$ elongated structural dome (Fig. 2). The apparent prevalence of NE-dipping planes is due to

274 oversampling of $S_{2}$ planes within the ETSZ. $S_{1}$ planes show instead a $N 170^{\circ} E$ preferred 
orientation (Fig. 2). $\mathrm{S}_{2}$ generally displays dips between 0 and $45^{\circ}$ with very low dispersion

(Fig. 2c). $\mathrm{S}_{1}$ dip shows instead a higher dispersion (from 0 to $90^{\circ}$ ) depending on the degree of

$D_{2}$ reworking. Structural relationships between $S_{2}$ and $S_{1}$ were studied in detail along the main road from St-Florent to Bocca di Vezzu (see location on Fig. 2a). Deformation appears heterogeneously distributed with lenses-shaped domains associated to rocks showing no or only a weak record of $\mathrm{D}_{2}$ deformation (see grey domains in Fig. 2b) and surrounded by anastomosed $\mathrm{D}_{2}$ corridors (see $\mathrm{S}_{2}$ trajectories in Fig. $2 \mathrm{~b}$ ). Low-strain domains consist in lenseshaped volumes of both unstrained Variscan magmatic rocks and weakly deformed facies, with incipient flat to gently dipping $\mathrm{S}_{1}$. The largest one occurs in the core of the Tenda massif and roughly corresponds to the cartographic outline of the Casta granodiorite (Fig. 2). When weakly reworked by $\mathrm{D}_{2}, \mathrm{~S}_{1}$ exhibits small- to large-scale undulations (Fig. 3a). With increasing $D_{2}$ reworking, $S_{1}$ is involved into recumbent isoclinal $D_{2}$ folds whose axial planes correspond to shallowly dipping $S_{2}$ crenulation cleavage (Figs. $3 b$ and $3 c$ ). Both $S_{1}$ and $S_{2}$ carry a mineral association mainly made of quartz, albite and phengite in most granites, but in more mafic facies, blue-amphiboles highlight the folded $\mathrm{S}_{1}$, and is retrogressed into chlorite in $S_{2}$ cleavage (Fig. 3d). In those typical outcrops characterized by $D_{2}$ folds, envelopes of $S_{1}$ are 291 steeply dipping and strike NNW-SSE while $\mathrm{S}_{2}$, in the same range of strike, is shallowly dipping (Fig. 3e). The associated $\mathrm{D}_{2}$ folds axes also trend NNW-SSE with gently dipping 293 plunges.

With increasing $D_{2}$ strain intensity, $S_{1}$ can be almost completely transposed into the $S_{2}$ 295 fabric, especially along the Saleccia Shear Zone (SSZ) and the ETSZ where it can be 296 observed at landscape-scale (Figs. 3f and 3g, respectively). The uppermost structural levels of the ETSZ show a single $S_{2}$ fabric that is itself involved in metric to decametric recumbent isoclinal folds in a progressive $\mathrm{D}_{2}$ deformation (i.e. the $\mathrm{D}_{3}$ folds of Molli et al., 2006). The 
sheath folds, with trends axes evolving from NW-SE to ENE-WSW (Figs. 3h and 3i),

301 parallelizing to the local stretching (Fig. 4). Dimensions of $\mathrm{D}_{2}$ folds across the massif vary 302 from a few centimeters to several tens of meters.

\subsection{Stretching lineations}

305

Stretching lineation is defined by various markers, depending primarily on the nature

of the protolith and the strain intensity. For both $\mathrm{D}_{1}$ and $\mathrm{D}_{2}$, stretching lineation is marked in granites by stretched quartz rods, truncation of feldspar, strain shadows, and more commonly by elongated phyllosilicate aggregates such as phengite. Similarly, stretching lineation is conspicuous in metasediments. It is marked by fine-grained slates of phyllosilicates in pelitic layers or by the elongation of stretched pebbles in metaconglomerate layers. More rarely, it is marked by the alignment and truncation of prismatic minerals such as blue-amphiboles. In most outcrops, the orientation of the various types of lineation is fairly constant. Just as $\mathrm{S}_{2}, \mathrm{~L}_{2}$

314 is ubiquitous across the massif but is particularly marked in the vicinity of the ETSZ and

315 second-order shear zones. Conversely, $\mathrm{L}_{1}$ is only locally expressed and restricted to low-strain 316 domains.

A total of $166 \mathrm{~L}_{1}$ and $408 \mathrm{~L}_{2}$ orientations have been measured in all lithologies across

318 the Tenda massif (Fig. 4a). $\mathrm{L}_{1}$ planes were only measured where they have not been 319 verticalized during $\mathrm{D}_{2}$. Trend and plunge of the different stretching lineations are almost 320 comparable and show low dispersion (Fig. 4b) with a mean orientation of $\mathrm{N} 050^{\circ} \mathrm{E}-\mathrm{N} 060^{\circ} \mathrm{E}$ 321 and a dominant NE-plunge related to the oversampling of $\mathrm{S}_{2} / \mathrm{L}_{2}$ fabrics within the ETSZ. 322 However, a slight yet reproducible difference in trends can however be detected at the scale of 323 the outcrop. Consistent with the overall dome geometry, both $\mathrm{L}_{1}$ and $\mathrm{L}_{2}$ lineation mostly 
324 plunge to the northeast in the northeastern flank and to the southwest in the southwestern 325 flank.

4. Kinematics of the polyphased deformation

Kinematics of deformation recorded in the Tenda massif is complex and characterized

330 by the progressive overprint of opposing shear senses. The early subduction-related top-tothe-SW deformation is largely overprinted by the late top-to-the-NE extensional shear that prevailed during exhumation (e.g. Mattauer et al., 1981; Jolivet et al., 1990; 1991; Fournier et al., 1991; Daniel et al., 1996; Gueydan et al., 2003; Molli and Tribuzio, 2004; Molli et al., 2006; Maggi et al., 2012, 2014; Rossetti et al., 2015). In this section, $\mathrm{D}_{2}$ features are analyzed

335 first and $\mathrm{D}_{1}$ next in order to properly unfold the sequence of top-to-the-NE and SW-directed deformations and adequately characterize their relative contribution to the finite geometry of 337 the massif.

4.1. Description and distribution of top-to-the-NE deformation $\left(\mathrm{D}_{2}\right)$

Top-to-the-NE deformation is heterogeneously distributed within the Tenda massif

342 (Figs. 4a and 5). It concentrates, at the first glance, toward the higher parts of the dome in the 343 vicinity of the ETSZ and therefore mantles a relatively less deformed core preserving $\mathrm{D}_{1}$

344 features (Fig. 5a). This deformation is spectacularly exposed within the northern outcrop of 345 the ETSZ where a ca. 200 m-thick NE-dipping mylonites are classically described (Jolivet et 346 al., 1990; 1991; Fournier et al., 1991; Daniel et al., 1996; Gueydan et al., 2003; Molli and 347 Tribuzio, 2004; Molli et al., 2006; Maggi et al., 2012, 2014; Rossetti et al., 2015). Due to the 348 dome-shaped architecture of the Tenda massif, top-to-the-NE deformation displays gentle to 
moderate northeastward dips and normal-sense relative displacements on the northeastern

350 flank of the dome while it often presents flat or even "reverse" geometry on the southwestern 351 flank in the vicinity of the Ostriconi fault (Fig. 5a). This first-order geometry hides smaller352 scale yet abundant top-to-the-NE structures that are particularly relevant for the discussion. 353 Those observations are projected along the synthetic cross section presented in Fig. 5.

First, top-to-the-NE deformation also concentrates toward another shear zone of prime importance, the Saleccia Shear Zone (SSZ) that is described for the first time in this study (see Fig. 3f). There, $\mathrm{D}_{2}$ deformation occurs within granitoids roughly $1 \mathrm{~km}$ structurally below the ETSZ and evolves upward from gently NE-dipping protomylonites preserving $\mathrm{D}_{1}$ subvertical fabrics, to mylonites and ultimately rare stripes of ultramylonite bodies over a ca. $150 \mathrm{~m}$-thick strain gradient where deformation localizes within the Saleccia rhyolite (Fig. 5b). In this gradient, the mylonitic $S_{2}$ strikes NW-SE and moderately dips to the northeast (Fig. 3f). In the most deformed domains of the SSZ, spacing between $\mathrm{D}_{2}$ shear bands is locally as low as 0.5 to $1 \mathrm{~cm}$ (Fig. 5b) and it increases downward, leaving lens-shaped domains where $\mathrm{S}_{1}$ is 363 preserved.

Top-to-the-NE deformation also occurs as 10-50 cm-thick localized shear zones that rework previous fabrics or even undeformed protolith. Within the most deformed rock volumes, spacing between shear bands is locally as dense as 1-2 cm. Away from the core of shear zones, asymmetry and more generally imprint of $\mathrm{D}_{2}$ deformation decreases over a short distance (Fig. 5c). Locally, shear zones at high angle with respects to the main foliation suggest a brittle component during top-to-the-NE deformation (Fig. 5d). These narrow shear zones are consistently NE-dipping from the west to the east of the Tenda massif (Figs. 5a, 5c and 5d), crosscutting the large-scale dome structure. 
374 of compositional layering or dykes) are asymmetrically boudinaged within more ductile

375 metapelites. On the main D81 road, lenses of meta-rhyolite intrusions display a sigmoidal

376 internal $S_{2}$ foliation consistent with an overall top-to-the-NE sense of shear (Fig. 5e). In the

377 bulk of those intrusions, the $S_{1} / L_{1}$ fabrics are involved in recumbent isoclinal $D_{2}$ folds with

378 the development of a $S_{2}$ crenulation cleavage with a low $\left(\sim 20^{\circ}\right)$ westward dip (Fig. 5f).

The reactivation of pre-existing shallow-dipping discontinuities also occurs in the

380 vicinity of the intrusive contact between the western granitic complex and the volcano-

381 sedimentary country-rocks. Such is the case at the Punta di Mignola (see Fig. 2 for location)

382 where top-to-the-NE mylonites occur as a $20 \mathrm{~m}$-thick shear zone that overprints the primary

383 intrusive contact that is preserved as partially transposed granitic dykes asymmetrically

384 boudinaged within the metasedimentary matrix (Fig. $5 \mathrm{~g}$ ). Despite the preservation of primary

385 intrusive boundaries, their igneous protolithic texture is hardly recognizable. Here again, 386 shear bands present an apparent flat/reverse geometry.

387 Due to the scarcity of index minerals in most of the rocks, the physical conditions that prevailed during top-to-the-NE deformation are not easy to retrieve continuously. In the most mafic lithologies, top-to-the-NE shearing can be associated with the boudinage or even the

390 truncation of blue-amphiboles (Figs. 5h and 5i). In these rocks, a second generation of small391 scale blue-amphibole can occur during this $\mathrm{D}_{2}$ stretching but gaps between the fragments of

392 large blue-amphiboles and along the top-to-the-NE shear bands are mostly recorded during 393 crystallization of chlorite (Fig. 5i). In more felsic granitic lithologies that represent most of

394 the Tenda massif, the top-to-the-NE mylonites of the ETSZ are made of quartz, albite and 395 phengite that are sometimes associated with chlorite and pyrite (Fig. 5j). 
Top-to-the-SW deformation is located in the same structural level as rocks only

400 affected by $S_{1}$ that wrap unstrained Variscan magmatic rocks (compare Figs. $2 b$ and $4 a$ ).

401 Study of top-to-the-SW deformation has therefore been restricted to the exploration of the

402 lower parts of the dome along sections showing the upward development of $S_{1}$ and the

403 associated simple shear markers at the expense of the Variscan magmatic protoliths.

In the core of the less deformed domains (Fig. 2b), the inherited Variscan magmatic paragenesis including K-feldspar, plagioclase, quartz, biotite and hornblende is metastably preserved within incipient coronitic reactions. Among the most obvious reactions, hornblende is statically transformed to blue-amphibole. These domains, which display no perceptible deformation, are surrounded by rocks affected by $\mathrm{S}_{1} / \mathrm{L}_{1}$ tectonites. While the base of this strain gradient is dominated by less non-coaxial deformation, it rapidly evolves toward top-tothe-SW simple shear deformation marked by the development of a single set of shear bands (Figs. 4a and 5a). Besides, this strain gradient is further complicated by more local strain 412 localization, even at the scale of a single outcrop, as exampled by the base of the ETSZ, along 413 the main D81 road (Figs 6a, 6b, 6c). Here, top-to-the-SW deformation can occur as localized 414 shear bands that overprint a volume of rocks devoid of visible deformation (Fig. 6a). In this 415 case, $S_{1}$ only develops near shear bands and passes laterally to the undeformed protolith. 416 Shear bands can also work as limits between isotropic granite on one side and oblique $\mathrm{S}_{1}$ on 417 the other side. Those observations suggest that prior or during formation of $S_{1}, D_{1}$ deformation 418 started along discrete precursors in the form of shear bands. In this case, the flat orientation of 419 shear bands appears controlled by the orientation of the precursor. Within the most deformed 420 volumes of this outcrop, $\mathrm{D}_{1}$ deformation is more distributed, with regularly spaced top-to-the421 SW shear bands with $S_{1}$ sigmoidal (Fig. 6b). In this context, typical spacing between shear 422 planes varies between 1 and $3 \mathrm{~cm}$, depending on the size of magmatic K-feldspar clasts, and 423 they dip to the west. $S_{1}$ appears generally flat, highlighted by stretched quartz ribbons 
alternating with feldspar ribbons. The most deformed parts of this outcrop are concentrated in a very gently dipping high strain shear band showing a fast lateral widening from less than $1 \mathrm{~cm}$ up to $\sim 10 \mathrm{~cm}$ (Fig. 6c). Near the core of the ETSZ, $\mathrm{D}_{1}$ deformation is occasionally preserved from $\mathrm{D}_{2}$ as small-scale lens-shaped domains that often show internal mylonitic deformation (Fig. 6d). There, both the $S_{1}$ and the top-to-the-SW shear planes show evidence of passive rotation as they now dip eastward. Field observations on those structural levels indicate that when both top-to-the-SW and -NE shear criteria coexist, the first ones are always crosscut by the second ones (Fig. 6e).

In granitic lithologies, physical conditions that prevailed during top-to-the-SW deformation are generally not easy to retrieve. Blue-amphiboles sporadically develop either along the $\mathrm{S}_{1}$ or along the top-to-the-SW shear bands. Conversely, more mafic lithologies, topto-the-SW shearing appears clearly associated with the growth of synkinematic blueamphiboles (Fig. 6d).

5. Mapping the state of finite deformation within the Tenda granites

5.1. Approach and methodology

Variably strained granite constitutes the dominant lithology in the east of the Tenda massif. Granitic protoliths appear well suited to determine local and regional variations in the magnitude of deformation, either qualitatively or quantitatively. Quantitative estimates as retrieved from image analysis (e.g. Launeau and Robin, 2005) or anisotropy of magnetic susceptibility analysis (e.g. Borradaile and Jackson, 2010) are valuable in such contexts but are often local in extent. To put constraints on the large-scale pattern of deformation (> 100 $\mathrm{km}^{2}$ ), exhaustive mapping of the state of finite deformation has been applied qualitatively as 
described in Huet et al. (2009), Charles et al. (2011), and Laurent et al. (2015). Laurent et al.

450 (2015) have shown a good correlation between this qualitative approach and quantitative 451 methods.

As discussed above, the effects of $D_{1}$ and $D_{2}$ can be generally unambiguously separated. The intensity of the $\mathrm{D}_{2}$ overprint, however, is locally so severe as to allow only the $\mathrm{D}_{2}$ finite deformation pattern to be continuously mapped across the massif. Five strain grades were distinguished to describe the intensity of deformation across the protolith (Fig. 7). Geometric embedding of the different strain grades is presented on figure 8 .

- Grade 0 corresponds to rocks that did not experience significant $\mathrm{D}_{2}$ deformation,

such as $\mathrm{D}_{2}$ folds, $\mathrm{S}_{2}, \mathrm{~L}_{2}$ or top-to-the-NE simple shear indicators. Within this grade, rocks may be either coarse grained or mylonitized during $\mathrm{D}_{1}$. Thus, two sub-grades were distinguished.

Grade 0 s.s. corresponds to the undeformed protolith characterized by an equant fabric where blue-amphiboles can statically replace magmatic hornblende (Figs. 7a and 7b). Besides, grade OW corresponds to any other rocks deformed during $\mathrm{D}_{1}$ and showing typical features such as top-to-the-SW shear bands, $S_{1}$ or $L_{1}$ but no trace of $D_{2}$ deformation (Fig. $7 \mathrm{c}$ ).

- Grade 1 characterizes rocks that experienced incipient $\mathrm{D}_{2}$ deformation superimposed on $\mathrm{D}_{1}$ features. In the field, typical examples are outcrops showing $\mathrm{D}_{2}$ folds associated with two different fabrics: a steep and folded $S_{1}$ and a sub-horizontal $S_{2}$ crenulation cleavage (Figs. $3 b, 3 c, 3 d, 5 f$ and $7 d)$. There, $S_{1}$ can be either gently folded or strongly crenulated. However, it shows in any case a pure shear component corresponding to subvertical shortening. $\mathrm{D}_{1}$ topto-the-SW shear bands may be locally preserved associated with the sigmoidal character of $\mathrm{S}_{1}$. In those cases, top-to-the-SW shear bands and $\mathrm{S}_{2}$ planes have comparable orientations, suggesting that shear bands represented weak zone where $S_{2}$ lately localized. 
main feature. In some cases, $S_{2}$ crenulation planes are used as shear bands (Fig. 7e). In this case, $\mathrm{S}_{1}$ is comprised and between $\mathrm{S}_{2}$ planes, indicating top-to-the-NE shearing. In other cases, newly formed top-to-the-NE shear bands affect a sigmoidal $\mathrm{S}_{2}$ (Fig. 7f). Angle between shear planes and foliation is about $60^{\circ}$.

Increasing degree of simple shear from grades 2 to 4 is then recorded by an overall decrease of both spacing between top-to-the-NE shear bands and the angle between the $\mathrm{S}_{2}$ and the shear bands, responsible for the progressive transposition of $\mathrm{D}_{1}$ structures (Figs. $7 \mathrm{f}$ to $7 \mathrm{~h}$ ). - Transition between grades 2 and 3 is marked by the occurrence of top-to-the-NE shear bands that are regularly spaced between 5 and $10 \mathrm{~cm}$, affecting a sigmoidal $\mathrm{S}_{2}$ (Fig. 7f). The angle between shear bands and foliation can be bracketed between 30 and $60^{\circ} . \mathrm{D}_{2}$ folds are more rarely preserved, and shear bands dominate.

- Transition between grades 3 and 4 is marked by a decreasing angle between top-tothe-NE shear bands and $\mathrm{S}_{2}$, beneath $30^{\circ}$ (fig. $7 \mathrm{~g}$ ). This flattening of mylonites is responsible for nearly complete obliteration of $\mathrm{D}_{2}$ folds, rarely still visible, and the regular spacing of shear bands near $1 \mathrm{~cm}$.

- Grade 4 corresponds to the most deformed volumes, being characterized by occurrence of ultramylonites and by the almost total transposition of $\mathrm{S}_{2}$ (Fig. 7h).

The increase of finite strain intensity is therefore associated with a progressive increase of the simple shear component of deformation, from vertical shortening and folding of $S_{1}$ to top-to-the-NE simple shear deformation. In this frame, the angle between top-to-the$\mathrm{NE}$ shear planes and $\mathrm{S}_{2}$ progressively closes with the progressive reworking of the remaining $\mathrm{D}_{1}$ structures (Fig. 8).

\subsection{Grade distribution}


500 applying this high-resolution strain intensity scale. In the cases of mixed grade for a same 501 outcrop, overprinted structures (grade n-1) are generally boudinaged between anastomosed zones of overprinting structures (grade $n$ ). Local variations in deformation grade thus appear as snapshots of a continuum of deformation. This observation can be made at different scales (Fig. 9). To clarify the regional pattern, local mixed-grade stations are qualified with a single grade. Grade n-1 is chosen if it clearly represents a large part of the outcrop. For equalproportion between grades $n$ and $n-1$, grade $n$ is chosen because it better represents the finite structure, as it appears as the latest phase. The resulting map, comprising 617 outcrops homogenously distributed within the granitic complex, is shown on figure 10a. Four cross sections normal to the regional foliation and parallel to stretching are presented on figure $10 \mathrm{~b}$. At the massif scale, the map shows that $\mathrm{D}_{2}$ affects a large part of the mapped area, except for the Casta granodiorite, which remains isotropic or only affected by $\mathrm{D}_{1}$ (cross sections $\mathrm{BB}^{\prime}$ and $\mathrm{DD}^{\prime}$ on Fig. 10). $75 \%$ of the investigated outcrops are affected by $\mathrm{D}_{2}$.

513 Among those outcrops, $28 \%$ are represented by grade 1 and $30 \%$ by grade 2 . Grades 3 and 4

514 domains are of secondary importance, $24 \%$ to $18 \%$ respectively, a trend nicely indicating a

515 localization of deformation with increasing finite strain. This distribution is shown both on the 516 map and in the cross sections where the deformed zones become narrower with increasing 517 strain intensity. At first-order, strain intensity clearly increases from west to east, toward the 518 ETSZ (cross sections BB', CC', DD' on Fig. 10) and the SSZ (cross section AA' on Fig. 10). 519 At a smaller scale, deformation zones also occur as isolated shear zones of moderate intensity 520 (grade 2) in poorly deformed zones (grade 1) near Mt Genova (cross section BB' on Fig. 10). 521 Similarly, isolated high-intensity shear zones (grade 4) occur in moderately deformed 522 volumes within the ETSZ (cross section CC' on Fig. 10). The overall 3-D structure of the 523 massif thus appears as a heterogeneous shear zone showing: i) a first-order strain gradient 
toward the ETSZ and the SSZ, ii) isolated strain gradients at a smaller scale. As observed at

525 different scales (Fig. 9), zones dominated by structures related to grade n-1 appear as lenses or 526 boudins between zones affected by grade $\mathrm{n}$ (Fig. 10).

6. Discussion

529

Structural studies on the Tenda massif have been so far conducted on its eastern part, 531 the ETSZ, an excellent example of polyphased contact accommodating both burial and exhumation of continental material (Daniel et al., 1996; Brunet et al., 2000; Gueydan et al., 2003; Molli and Tribuzio, 2004; Molli et al., 2006; Maggi et al., 2012; 2014; Rossetti et al., 2015). However, behavior of a large-scale continental crust portion and particularly strain accommodation of subduction and exhumation cannot be explored only by the detailed study of the major contacts where deformation is particularly concentrated. Our results show that deformation of the Tenda massif was not restricted to the ETSZ. Field results show the distribution of retrograde deformation related to exhumation and the pattern of partial to total transposition of the inherited top-the-SW fabric. One of the most important observation is that

540 the later NE-directed (exhumation-related) structures are pervasively recorded across the 541 entire massif. In the lights of these results, this section discusses the variation of strain 542 distribution during burial and exhumation as well as the factors responsible for strain 543 localization. Regional implications are presented first.

545 6.1. A review of the Tenda massif finite structure: regional implications on the model of 546 subduction/exhumation 
549 the uncertain attribution of some structures to one of the different tectonic phases; 2) the focus 550 of previous work on the ETSZ, that led to different descriptions of finite structure and patterns 551 of strain distribution (Daniel et al., 1996; Brunet et al., 2000; Gueydan et al., 2003; Molli and 552 Tribuzio, 2004; Molli et al., 2006; Maggi et al., 2012; 2014; Rossetti et al., 2015); 3) the 553 scattering and various interpretation of chronological constraints. We discuss these three 554 points in the next subsections.

6.1.1. To which deformation stage folds and crenulated structure belong? the models presented in the section 2.2. They can develop in coaxial domain of deformation between top-to-the-NE shear zones during exhumation in greenschist-facies conditions (Jolivet et al., 1990; 1991; Daniel et al., 1996) or can occur in low-strained domains in between zones of localized top-to-the-SW shearing in blueschist-facies conditions (Molli et al., 2006; Rossetti et al., 2015). Our study shows that: 1) top-to-the-SW shearing can display different amounts of strain localization from distributed to strongly localized in a same outcrop without developing any crenulation (Fig. 6). 2) On the contrary, crenulation is rather localized where top-to-the-NE shearing occurs at outcrop scale (Figs. 5e, 5f, 7e, 7f and 9). This is also true for larger scales. For example, undulations of vertical $S_{1}$ in the Mt Genova (Fig. 3a) occur in between two top-to-the-NE shear zones (Fig. 10). 3) This crenulation $\left(\mathrm{S}_{2}\right)$ is associated to retrogression of blue-amphiboles, which developed in $\mathrm{S}_{1}$, into chlorite, suggesting that $S_{1}$ and $S_{2}$ did not develop in the same $P-T$ conditions (Fig. 3d). For these reasons, we followed the model of Jolivet et al. (1990; 1991) and Daniel et al. (1996),

572 according to which the crenulated structures are rather linked to $\mathrm{D}_{2}$. 
574 the Cap Corse antiform (Fig. 1; Jolivet et al., 1991). There, the NE-verging recumbent folds are observed from a few centimeters to hundreds of meters and they are later sheared by topto-the-E shear zones and cut by the brittle detachment observed near the northernmost tip of Cap Corse (Macinaggio detachment, Fig. 1). Thus, the two antiforms, namely the Tenda massif and the Cap Corse, show the same general asymmetry with a localized east-dipping shear zone at the top with folds overturned to the east underneath. This shows that these folds are not restricted to the Tenda massif but are instead characteristic of the late architecture of Alpine Corsica, including the Tenda massif and the Schistes Lustrés nappe as two separate crustal-scale boudins formed during extension (Daniel et al., 1996).

\subsubsection{Global strain distribution in the Tenda massif}


top-to-the-NE shear criteria) that rework $\mathrm{D}_{1}$ structures $\left(\mathrm{S}_{1}, \mathrm{~L}_{1}\right.$ and top-to-the-SW shear

599 criteria). The relatively more deformed carapace mantles a less deformed core which can

600 locally preserves undisturbed $\mathrm{D}_{1}$ structures. From west to east, this dome is crosscut by late

601 top-to-the-NE narrow and localized shear zones that evolve toward a brittle behavior (Figs.

$6025 \mathrm{a}, 5 \mathrm{c}$ and $5 \mathrm{~d}$ ). We then emphasize the fact that $\mathrm{D}_{2}$, top-to-the-NE shearing, and switch of the

603 ETSZ from a thrust to a detachment were mostly recorded in the ductile field, and pervasively

604 affect the finite structure of the Tenda massif.

605

606 6.1.3. Geodynamic context for the exhumation of the Tenda massif

607

A major controversy exists about the respective part of regional compression and extension in the exhumation of the Tenda massif (see debate in Molli et al., 2006). The rather cold path of the exhumation favors a first step of syn-orogenic exhumation (Molli and

611 Tribuzio, 2004; Molli et al., 2006; Maggi et al., 2012), also envisaged for more external 612 continental units (i.e. the Popolasca unit for example; Malasoma and Marroni; 2007; Di Rosa 613 et al., 2016). Instead, the end is clearly recorded during post-orogenic extension in 614 greenschists-facies to brittle conditions, affecting the whole nappe stack (Molli and Tribuzio, 615 2004; Molli et al., 2006; Malasoma and Marroni; 2007; Maggi et al., 2012; Di Rosa et al., 616 2016). Syn-orogenic exhumation may involve a thrust at the base and a detachment (or 617 exhumation fault) at the top of the exhumed units (e.g. Chemenda et al., 1995; Raimbourg et 618 al., 2005), whereas post-orogenic extension will rework the entire nappe stack. In the case of 619 the Tenda massif, Molli et al. (2006) concluded that syn-orogenic exhumation has been 620 responsible for most of the exhumation below the detachment situated between the Schistes 621 Lustrés nappe and the Nappe Supérieures and accommodated by a thrust at the base of the 622 Tenda massif. Unfortunately, this structural architecture cannot be proven because the basal 
contact of the Tenda massif does not crop out anywhere (Fig. 5a). Only chronological

624 constraints permit to discuss this problem (see Fig. 11).

A regional shift from compression to extension has been widely recognized from the

Gulf of Lion to the Calabrian Arc in connection with the southeastward retreat of the Apennine slab (e.g. Malinverno and Ryan, 1986; Doglioni, 1991; Gueguen et al., 1998; Jolivet et al., 1998; 2008; 2015; Séranne, 1999; Brunet et al., 2000; Rossetti et al., 2001; Speranza et al., 2002; Faccenna et al., 2004). As attested by evidences of compression in Late Eocene-Early Oligocene sedimentary rocks of Sardinia (Faccenna et al., 2002) and syn-rift sediments of Middle Oligocene to Aquitanian age (23-20 Ma) in the Gulf of Lion (e.g. Séranne, 1999; Oudet et al., 2010; Jolivet et al., 2015), the shift from compression to extension occurred in the Oligocene probably near the Late Rupelian (34-28 Ma). Similarly, syn-rift sediments formed during Late Oligocene-Aquitanian times in Corsica and Sardinia, prior to their anticlockwise rotation as a rigid block during the spreading of the LiguroProvençal Sea (e.g. Faccenna et al., 2002; Speranza et al., 2002; Ferrandini et al., 2003).

638 its prograde increments (U-Pb on acmite-phengite-coatings, Maggi et al., 2012) and Early

639 Oligocene for its waning stage (Brunet et al., 2000; Rossetti et al., 2015). The end of top-to640 the-SW shearing at this time is coherent with Late Eocene-Early Oligocene HP-LT peak ages 641 in the more buried levels of the Schistes Lustrés nappe (Martin et al., 2011; Vitale Brovarone 642 and Herwartz, 2013) and with the post-Bartonian HP-LT thrusting in the external domains 643 (Bonnal et al., 1973; Bézert and Caby, 1988; Jourdan, 1988; Egal and Caron, 1989; Vitale 644 Brovarone et al., 2013) that all constrain the beginning of syn-orogenic exhumation. Recent $645{ }^{40} \mathrm{Ar} /{ }^{39} \mathrm{Ar}$ ages on Alpine shear zones developing in the eastern Variscan basement argue for a 646 major shearing during HP-LT peak at 37-35 Ma, before exhumation near $32 \mathrm{Ma}$ (Di Vincenzo 647 et al., 2016). As a conclusion, the syn-orogenic exhumation of the relatively internal domain 
648 of Alpine Corsica (i.e. Schistes Lustrés nappe and Tenda massif) is narrowly constrained

649 between $\sim 38-32$ Ma that is a maximum limit for HP-LT peak in the Schistes Lustrés nappe

650 and for thrusting in the external domain, and $\sim 32-30 \mathrm{Ma}$, during exhumation of the entire

651 Alpine Corsica, synchronously with the regional compression-extension switch. This could

652 happen when Corsica passed from an east-dipping Alpine subduction to the back-arc domain

653 of the west-dipping Apennine subduction system near 35-30 Ma (e.g. Molli and Malavieille,

654 2011; Malusà et al., 2015).

655 The regional compression/extension switch is recorded by $\mathrm{Rb}-\mathrm{Sr}$ (Rossetti et al., 2015)

656 and ${ }^{40} \mathrm{Ar} /{ }^{39} \mathrm{Ar}$ (Brunet et al., 2000) ages on phengite affected by $\mathrm{D}_{1}$ and $\mathrm{D}_{2}$ in both the Schistes

657 Lustrés and the Tenda units. In the Tenda massif, crystallization or re-crystallization of 658 relatively substituted $\mathrm{D}_{1}$ phengite $\left(\mathrm{Si}^{4+} \sim 3.5\right.$ a.p.f.u $)$ during deformation in samples 659 characterized by top-to-the-W kinematics are dated between 32 and $27 \mathrm{Ma}$ by the $\mathrm{Rb}-\mathrm{Sr}$ 660 method while the ${ }^{40} \mathrm{Ar} /{ }^{39} \mathrm{Ar}$ one gives a minimum age of $35 \mathrm{Ma}$. The end of $\mathrm{D}_{2}$ deformation is 661 recorded in highly deformed samples characterized by top-to-the-NE kinematics and 662 relatively less substituted phengite $\left(\mathrm{Si}^{4+} \sim 3.3\right.$ a.p.f.u $)$ at 20 and $25 \mathrm{Ma}$ by the $\mathrm{Rb}-\mathrm{Sr}$ and $663{ }^{40} \mathrm{Ar} /{ }^{39} \mathrm{Ar}$ methods, respectively. The same ages are recorded in strongly retrogressed samples 664 of the Schistes Lustrés nappe during $\mathrm{D}_{2}$. The systematic difference of $5 \mathrm{Ma}$ observed between 665 the two methods questioned their ability to precisely date the timing of deformation. 666 Accordingly, the compression/extension switch is differentially constrained near $27 \mathrm{Ma}$ 667 (Rossetti et al., 2015) or 32 Ma (Brunet et al., 2000). Further investigation are needed to 668 precisely constrain the absolute timing of deformation relative to the different events. 669 However, the two datasets indicate that the relative time between the ends of the two events is 670 about $\sim 7 \mathrm{Ma}$, showing that post-orogenic movements probably accommodated a non671 negligible part of the exhumation.

672 
Many studies on strain localization and shear zone development have focused on cases where $P-T$ conditions remained constant through deformation. The Tenda massif offers instead an example where the distribution of deformation can be studied through variable $P-T$ conditions during a full burial/exhumation cycle.

679 the Tenda massif (Jourdan, 1988; Rossi et al., 2001; Vitale Brovarone et al., 2013) shows that it was near the surface just before its burial, as the Alpine events in external units started during the Bartonian (40 Ma; Bonnal et al., 1973; Bézert and Caby, 1988; Jourdan, 1988; Egal and Caron, 1989; Vitale Brovarone et al., 2013). Then, blueschist-facies conditions are recorded during $D_{1}$ as attested by crystallization of blue-amphibole along $S_{1}$ (Figs. $3 c$ and 3d) and top-to-the-SW shear bands (e.g. Molli et al., 2006). At large-scale, blue-amphibole occurs principally in the Mt Asto granite, within the ETSZ (Fig. 2), suggesting that its occurrence 690 depends in part on chemical composition of the protoliths and that it is favored by 691 deformation. Despite this observation, blue-amphibole also occurs statically in non-deformed 692 facies of the Casta granodiorite (Fig. 7b). Within the Mt Genova granite, two occurrences 693 have been observed (Fig. 2a), the first one along the main D81 road, in a fine-grained facies 694 strongly localizing deformation and the second one in micaschists of the Punta di Mignola 695 shear zone (Figs. 2a and 5g). Further south of our study area, blue-amphibole also occurs in 696 the westernmost parts of the Tenda massif (Near Urtaca, Jourdan, 1988; Molli and Tribuzio, 697 2004). The most reliable peak $P-T$ conditions constraints are provided by petrological studies 
in peculiar lithologies, away from the ETSZ, in the gabbroic complex of Bocca di Tenda,

699 south of the Tenda massif. Here, rhyolite with jadeite-bearing aegirine, Na-amphibole and

700 celadonite-rich phengite (Tribuzio and Giacomini, 2002) and gabbro with Al-poor hornblende

701 and celadonite-rich phengite (Molli and Tribuzio, 2004) constrain peak metamorphism near 1

$702 \mathrm{GPa}$ and $450{ }^{\circ} \mathrm{C}$. Similar results $\left(1.2 \mathrm{GPa}, 400{ }^{\circ} \mathrm{C}\right)$ are obtained in the ETSZ with a peculiar

703 clinopyroxene + rutile assemblage (Maggi et al., 2012). All those results suggest that the

704 Tenda massif recorded a global blueschists-facies condition during burial, and remained a 705 relatively coherent unit.

706 Even if the early brittle structures relative to burial have been completely overprinted

707 by the later ductile deformation, we propose that first stage of deformation was probably

708 localized along brittle thrust precursor, as observed in the Corte slices further south (Jolivet et

709 al., 1990). The following ductile $\mathrm{H} P$ - $\mathrm{LT} \mathrm{D}_{1}$ deformation $\left(\mathrm{S}_{1}, \mathrm{~L}_{1}\right.$, top-to-the-SW shearing $)$ is

710 on the contrary distributed at large scale, affecting a large volume of the Tenda massif, from

711 the core where it can preserve its original geometry, to the top of the dome where it is lately

712 overprinted (Figs. 5a and 12). Distributed deformation is evidenced by gneissic texture during

$713 \mathrm{D}_{1}$ (Maggi et al., 2012; 2014). At the scale of outcrop, we do not find any evidences of

714 structures related to the brittle-ductile transition for $\mathrm{D}_{1}$. However, in the less deformed

715 volume, we found that $S_{1}$ developed only along top-to-the-SW shear bands and passes

716 laterally to the undeformed protolith (Fig. 6a). Those observations suggest that $\mathrm{D}_{1}$

717 deformation started along discrete precursors in the form of shear bands prior or during

718 formation of $S_{1}$. It is coherent with studies focusing on the nucleation of shear zones where

719 the amount of later overprint is limited. They demonstrate that shear zones nucleate from

720 discrete precursors such as brittle fractures (e.g. Mancktelow and Pennacchioni, 2005;

721 Raimbourg et al., 2005; Goncalves et al., 2012; 2016; Sullivan et al., 2013), lithological

722 contacts (e.g. Pennacchioni and Mancktelow, 2007) or simply microscopic heterogeneities at 
mineral boundaries (e.g. Ingles et al., 1999). Finally, the top-to-the-SW shear bands are lately overprinted by brittle fractures, making the nature of the precursor uncertain. However, all those points argue for a first step of strain delocalization within the Tenda massif during burial and its first crossing through the brittle-ductile transition from surface up to blueschistsfacies conditions.

\subsubsection{Exhumation $\left(\mathrm{D}_{2}\right.$ phase $)$}

Structures related to exhumation were mostly recorded in greenschist-facies conditions, while blue-amphiboles were turned into chlorite in $\mathrm{S}_{2}$ crenulation and top-to-theNE shear bands (Figs. 3d and 5i). It seems reasonable that they developed from blueschistsfacies conditions, in a $\mathrm{D}_{1}-\mathrm{D}_{2}$ continuum deformation. Indeed, Molli et al. (2006) described a $\mathrm{D}_{2}$ crenulation made of fine grains of Na-amphibole showing an outward decrease of $\mathrm{Al}$, compatible with a decreasing pressure, between microlithons with large Na-amphiboles. We also find blue-amphibole recrystallization in the tails of older blue-amphibole sigma clasts compatible with top-to-the-NE shearing (see white square in Fig. 5i). The exhumation path can be constrained from $\sim 1 \mathrm{GPa}$ and $450{ }^{\circ} \mathrm{C}$ to $<0.5 \mathrm{GPa}$ and $300-400^{\circ} \mathrm{C}$ (Tribuzio and Giacomini, 2002; Molli and Tribuzio, 2004; Molli et al., 2006). The last increments of exhumation are recorded in the brittle field (Fig. 5d) in a continuum deformation, as the directions of both ductile and brittle stretching are consistent (Molli et al., 2006).

Right after the burial/exhumation switch, the first stages of $\mathrm{D}_{2}$ deformation are characterized by pervasive folding responsible for a general verticalization of $S_{1}$ envelope (Figs. 2c, 3e, 5a and 12). Folding is expressed in low-strain $\mathrm{D}_{2}$ domain by gentle undulations of $S_{1}$ (Fig. 3a) or inversely strongly crenulated $S_{1}$ associated to a flat $S_{2}$ cleavage (Figs. 3b, 3c, 3d), compatible with a pure shear component of deformation corresponding to a subvertical 
shortening. Larger-scale folds can be observed near Santo-Pietro-di-Tenda, where they affect

749 the contact between the Tenda massif and the Schistes Lustrés nappe (Molli et al., 2006).

750 Limbs of the Schistes Lustrés nappe incorporated into the ETSZ (see Punta di Cepo and

751 Fornali Bay in Fig. 2) also suggest a folding of this contact. Irrespective of these variations in

752 scale, this folding stage is observed throughout the Tenda massif affected by $\mathrm{D}_{2}$. In agreement

753 with Molli et al. (2006), we argue for a general strain delocalization at the time of $\mathrm{D}_{2}$,

754 responsible for the buckling and deactivation of the original thrust just before or after the $\mathrm{D}_{1^{-}}$

$755 \mathrm{D}_{2}$ switch (Fig. 12). Then, the strain intensity map shows that deformation is localized in

756 narrower top-to-the-NE shear zones that locally develop thick mylonites and locally

757 ultramylonites (Figs. 5, 7, 8 and 10). Furthermore, the transition from grade $\mathrm{n}-1$ to $\mathrm{n}$ is marked

758 by relatively poorly deformed boudins in a more deformed matrix (Fig. 9). Local variations in

759 deformation grade thus appear as snapshots of a continuum of deformation that finally

760 localized in the ETSZ and the SZZ, showing that $\mathrm{D}_{2}$ deformation progressively localized

761 during exhumation toward the two principal shear zones. This interpretation is further

762 supported by the decrease of ${ }^{40} \mathrm{Ar}{ }^{39} \mathrm{Ar}$ ages on phengites toward the ETSZ nappe from $\sim 45$ to

$76325 \mathrm{Ma}$ (Brunet et al., 2000). Since the ductile structures are lately crosscut by NE-striking

764 faults, the spatial and temporal relationships between the ETSZ and the SSZ are unclear.

765 Further studies should better asses both brittle kinematics and provide radiometric

766 chronological constraints also for the SSZ. In any case, the ETSZ and the SSZ are two

767 different structures, the ETSZ developing at the top of the Tenda massif while the SSZ is

768 structurally below and developed within the granitic complex (Fig. 10). Moreover, the two

769 shear zones are characterized by different stretching directions, NE-SW for the ETSZ and

770 NNE-SSW for the SSZ (Fig. 4a). Doming of the Tenda massif occurred during the

771 progressive strain localization toward the ETSZ as the $\mathrm{D}_{2}$ mylonites carapace near the top of

772 the massif is itself domed and outcrops in the west (Fig. 5). Besides, late top-to-the-NE 
narrow localized shear zones, showing a component of brittle deformation, always dip toward the northeast and are not affected by the doming. We suggest that this doming formed during regional extension near the brittle-ductile transition by a horizontal-axis rotation beneath the ETSZ where deformation progressively localized. The Tenda massif then record a relocalization of strain during its second crossing through the brittle-ductile transition zone, from strongly distributed at depth where exhumation began, to strongly localized in the upper levels of the crust, toward the brittle field (Fig. 12).

\subsection{Internal factors for strain distribution during burial and exhumation}

The two major shear zones of the Tenda massif are the ETSZ and the SSZ, where strain localizes toward lithological contacts between rocks of very contrasting rheology (Fig. 10). The fact that strain localizes in the ETSZ is comprehensible since the contact between the Tenda massif and the Schistes Lustrés nappe is both a zone of lithological/rheological contrast and a pathway for fluids (Maggi et al., 2012). In agreement with these authors, we find very heterogeneous second-order strain gradients in the ETSZ (see punctual observations of strain grades in Fig. 10). Maggi et al. (2012) explain it by alternating episodes of fluids-induced strain softening (feldspar-to-micas reaction) and strain hardening (neo-blastesis of K-feldspar) producing a rheological contrast that drives strain localization through a heterogeneous shear zone. But the internal lithological contacts are also preferentially used for strain localization. Indeed, most of those contacts are intensely deformed. This is true at the contact between: i) the granitic complex and the volcano-sedimentary sequence in the Punta di Mignola (Fig. 5g), ii) the Mt Genova and the Saleccia rhyolite in the SSZ (Figs. 5b and 10), or iii) the Mt Genova and the Casta granodiorite, east of Mt Genova (Fig. 10). This is in agreement with studies showing that shear zones nucleate on rheological heterogeneities such as brittle structures 

or lithological contacts (e.g. Pennacchioni and Mancktelow, 2007; Rennie et al., 2013) where strain remained localized.

$\mathrm{S}_{2}$ crenulation is well developed in these preferential zones for strain localization,

\section{2}

803

804

805

806 particularly in the vicinity of the SSZ and the ETSZ, where $S_{2}$ fabrics are visible at landscape scales (Figs. 3f and 3g). Inversely, in less deformed zone, $\mathrm{D}_{2}$ folds are rather characterized by $\mathrm{S}_{1}$ undulations without crenulation development (Fig. 3a). The fact that top-to-the-SW shear bands are privileged structures where $S_{2}$ develops (see section 5 about strain grades) suggests that penetrative $S_{2}$ fabrics visible in the major shear zones of the ETSZ are domain where topto-the-SW $\mathrm{D}_{1}$ shear zones initially localized during burial. Lithological contact thus is a primordial factor driving strain localization, directly for burial and $\mathrm{D}_{1}$ structures, and indirectly for exhumation and $\mathrm{D}_{2}$ structures, through a structural control of primarily deformation zone born during $\mathrm{D}_{1}$.

If lithological contact is a driving structure for strain localization, accommodation of deformation largely varies in function of the protolith. The best example is the Casta granodiorite that remained globally undeformed as it resisted in a large scale strain shadow. The Mt Genova also remained relatively poorly deformed with only few narrow shear zones situated structurally below and above. Inversely, deformation pervasively and intensely affected the Saleccia rhyolite and the Mt Asto monzogranite. Maggi et al. (2012; 2014) described the Casta granodiorite as the protolith of the ETSZ. However, we rather prefer the geological outline of Rossi et al. (1994) that shows that the ETSZ developed in the Mt Asto monzogranite. Indeed, when poorly deformed, it is clear that the ETSZ developed in a relatively felsic facies (Fig. 6a) compared to the Casta granodiorite that is more basic and characterized by a higher amount of hornblendes (Fig. 7a). Except for the Saleccia rhyolite that can deform easily due to its rather fine-grained matrix, the fact that plutonic granitoids 
823 behaved differently during deformation suggests that deformation mechanisms depend on the

824 composition of the protolith (X) as an internal parameter together with external parameters

825 such as fluids, $P-T$ conditions, associated with mineral transformations, as suggested for the

826 Tenda massif (Gueydan et al., 2003; Maggi et al., 2014) or other granites-related shear zone

827 (e.g. Goncalves et al., 2012; 2016; Oliot et al., 2010; 2014).

828

829

7. Conclusion

830

This structural study is based on a large dataset collected over most of the Tenda massif, providing new insights into its history from burial $\left(D_{1}\right)$ to exhumation $\left(D_{2}\right)$ :

- The first order finite structure of the Tenda massif is characterized by a NW-SE dome of $\mathrm{D}_{2}$ related structures $\left(\mathrm{D}_{2}\right.$ folds, $\mathrm{L}_{2}, \mathrm{~S}_{2}$ and top-to-the-NE shear criteria) mantling a less deformed core where $\mathrm{D}_{1}$ structures $\left(\mathrm{L}_{1}, \mathrm{~S}_{1}\right.$ and top-to-the-SW shear criteria) remain preserved in their initial position.

- Field evidence demonstrates that both $\mathrm{D}_{1}$ and $\mathrm{D}_{2}$ structures affect the whole massif.

Although $\mathrm{D}_{1}$ structures can still be encountered in their initial position, they are generally reworked by $\mathrm{D}_{2}$ deformation.

- Burial occurred from surface, where localized deformation was concentrated along

841 thrusts at the top of continental material (visible further south in Corte slices), until blueschist-

842 facies conditions where deformation was rather distributed, affecting both continental and 843 oceanic material.

- Exhumation probably started in a syn-orogenic context or simply at peakmetamorphic conditions, with delocalization of thrusting from the ETSZ toward the more external domains. $\mathrm{D}_{2}$ deformation then occurred firstly distributed through a general folding of previous structures, even the original thrust between the Tenda massif and the overlying 
848 Schistes Lustrés nappe. Through the switch from syn-orogenic to post-orogenic exhumation,

$849 \mathrm{D}_{2}$ localized in a set of large-scale shear zones including notably the ETSZ, located at the roof 850 of the dome between continental and oceanic material, and the SSZ, an internal shear zone 851 described for the first time. The general doming of $\mathrm{D}_{2}$ structures occurred during this strain 852 localization. The final increments are localized in the ETSZ and scattered in the rest of the 853 massif through narrow semi-brittle shear zones, not affected by doming.

854 - Lithological contacts were site of preferred localization, directly for burial and $\mathrm{D}_{1}$ 855 structures, and indirectly for exhumation and $\mathrm{D}_{2}$ structures, through a structural control of 856 primarily deformation zone born during $\mathrm{D}_{1}$. The deformation style and the tectonic coupling 857 between continental and oceanic material seem to have been mostly controlled by external 858 parameters, notably depth (i.e. $P-T$ conditions) in the wedge. However, the strain intensity 859 map shows that the amount of deformation depends at least in part on the protolith nature that 860 can, through an interaction with P-T-fluids conditions, have a strong impact on the 861 deformation style and the rheology of continental material.

863 Acknowledgments

The early stages of this work were conducted together with Christophe Brunet in the 866 framework of his PhD. Christophe sadly passed away while he was canoeing a river in the 867 Alps. This paper is dedicated to him. Giancarlo Molli, Emilien Oliot and Federico Rossetti are thanked for their constructive 869 comments and suggestions that improved the manuscript. This work has received funding 870 from the European Research Council (ERC) under the seventh Framework Programme of the 871 European Union (ERC Advanced Grant, grant agreement No 290864, RHEOLITH), from the 872 Institut Universitaire de France and from the Labex VOLTAIRE. 
Agard, P. \& Vitale-Brovarone, A. (2013). Thermal regime of continental subduction: The record from exhumed HP-LT terranes (New Caledonia, Oman, Corsica). Tectonophysics 601, $878 \quad 206-215$.

879

880 Beccaluva, L., Ohnenstetter, D. \& Ohnenstetter, M. (1981). K-Ar age determination on some 881 Tethyan ophiolites. Rendiconti della Societa Italiana di Mineralogia e Petrologia 37, 869-880. 882

883 Bellahsen, N., Jolivet, L., Lacombe, O., Bellanger, M., Boutoux, A., Garcia, S., Mouthereau, 884 F., Le Pourhiet, L. \& Gumiaux, C. (2012). Mechanisms of margin inversion in the external 885 Western Alps: Implications for crustal rheology. Tectonophysics 560-561, 62-83.

886

887

890

891

892

893

894

895

Bellanger, M., Bellahsen, N., Jolivet, L., Baudin, T., Augier, R. \& Boutoux, A. (2014). Basement shear zones development and shortening kinematics in the Ecrins Massif, Western Alps. Tectonics 33, 84-111.

Bézert, P. \& Caby, R. (1988). Sur l'âge post-bartonien des événements tectonométamorphiques alpins en bordure orientale de la Corse cristalline (Nord de Corte). Bulletin de la Societe Geologique de France 4, 965-971.

Bonnal, M., Parsy, A., Priou-Lacazedieu, A. \& Durand-Delga, M. (1973). Sur la structure de la Balagne sédimentaire (Corse). Comptes Rendus de l'Academie des Sciences de Paris 276, $1949-1952$. 
899 Borradaile, G. J. \& Jackson, M. (2010). Structural geology, petrofabrics and magnetic fabrics 900 (AMS, AARM, AIRM). Journal of Structural Geology 32, 1519-1551.

901

902 Brunet, C., Monié, P., Jolivet, L. \& Cadet, J. P. (2000). Migration of compression and 903 extension in the Tyrrhenian Sea, insights from Ar-40/Ar-39 ages on micas along a transect 904 from Corsica to Tuscany. Tectonophysics 321, 127-155.

905

906 Caron, J. M. (1994). Metamorphism and deformation in Alpine Corsica. Schweizerische 907 Mineralogische Und Petrographische Mitteilungen 74, 105-114.

908

909 Caron, J. M., Kienast, J. R. \& Triboulet, C. (1981). High-pressure-low-temperature 910 metamorphism and polyphase alpine deformation at Sant'Andrea di Cotone (eastern Corsica,

911 France). Tectonophysics 78, 419-451.

912

913 Caron, J. M. \& Péquignot, G. (1986). The transition beetween blue-schist and lawsonite 914 bearing eclogites on the example of corsican metabasalt. Lithos 19, 205-218.

915

916 Cavazza, W., DeCelles, P. G., Fellin, M. G. \& Paganellin, L. (2007). The Miocene Saint917 Florent Basin in northern Corsica: stratigraphy, sedimentology, and tectonic implications. 918 Basin Research 19, 507-527.

920 Charles, N., Gumiaux, C., Augier, R., Chen, Y., Zhu, R. \& Lin, W. (2011). Metamorphic 921 Core Complexes vs. synkinematic plutons in continental extension setting: Insights from key 922 structures (Shandong Province, eastern China). Journal of Asian Earth Sciences 40, 261-278. 
924 Chemenda, A. I., Mattauer, M., Malavieille, J. \& Bokun, A. N. (1995). A mechanism for syn925 collisional rock exhumation and associated normal faulting: Results from physical modelling. 926 Earth and Planetary Science Letters 132, 225-232.

928 Cohen, C. R., Schweickert, R. A. \& Odom, A. L. (1981). Age of emplacement of the schistes 929 Lustrés nappe, Alpine Corsica. Tectonophysics 73, 267-283.

930

931 Daniel, J. M., Jolivet, L., Goffé, B. \& Poinssot, C. (1996). Crustal-scale strain partitioning: 932 footwall deformation below the Alpine Oligo-Miocene detachment of Corsica. Journal of 933 Structural Geology 18, 41-59.

934

De Wever, P., Danelian, T., Durand-Delga, M., Cordey, F. \& Kito, N. (1987). Datations des 936 radiolarites post-ophiolitiques de Corse alpine à l'aide des radiolaires. Comptes Rendus de 1'Academie des Sciences de Paris 305, 893-900.

938

939 Di Rosa, M., De Giorgi, A., Marroni, M. \& Vidal, O. (2016). Syn-convergence exhumation of 940 continental crust: evidence from structural and metamorphic analysis of the Monte Cecu area, 941 Alpine Corsica (Northern Corsica, France). Geological Journal.

943 Di Vincenzo, G., Grande, A., Prosser, G., Cavazza, W. \& DeCelles, P. G. (2016). 40Ar-39Ar 944 laser dating of ductile shear zones from central Corsica (France): Evidence of Alpine (middle 945 to late Eocene) syn-burial shearing in Variscan granitoids. Lithos 262, 369-383. 
Doglioni, C. (1991). A proposal for the kinematic modelling of W-dipping subductions possible applications to the Tyrrhenian-Apennines system. Terra Nova 3, 423-434.

Durand-Delga, M. (1984). Principaux traits de la Corse Alpine et corrélations avec les Alpes Ligures. Memorie della Societa Geologica Italiana 28, 285-329.

Egal, E. \& Caron, J. M. (1989). Structures de l'Eocène autochtone en Corse. Comptes Rendus de l'Academie des Sciences de Paris 309, 1431-1436.

Faccenna, C., Piromallo, C., Crespo-Blanc, A., Jolivet, L. \& Rossetti, F. (2004). Lateral slab deformation and the origin of the western Mediterranean arcs. Tectonics 23, TC1012.

Faccenna, C., Speranza, F., D’Ajello Caracciolo, F., Mattei, M. \& Giacomo, O. (2002). Extensional tectonics on Sardinia (Italy): insights into the arc-back-arc transitional regime. Tectonophysics 356, 213-232.

Faure, M. \& Malavieille, J. (1980). Les plis en fourreau du substratum de la Nappe des Schistes Lustrés de Corse. Signification cinématique. Comptes Rendus de l'Academie des Sciences de Paris 290, 1349-1352.

Faure, M. \& Malavieille, J. (1981). Etude structurale d'un cisaillement ductile $\square$ : le charriage ophiolitique corse dans la région de Bastia. Bulletin de la Societe Geologique de France 23, $335-345$. 
971 Fellin, M. G., Vance, J. A., Garver, J. I. \& Zattin, M. (2006). The thermal evolution of

972 Corsica as recorded by zircon fission-tracks. Tectonophysics 421, 299-317.

973

974 Ferrandini, J., Gattacceca, J., Ferrandini, M., Deino, A. \& Janin, M.-C. (2003).

975 Chronostratigraphie et paléomagnétisme des dépôts oligo-miocènes de Corse $\square$ : implications

976 géodynamiques pour l'ouverture du bassin liguro-provençal. Bulletin de la Societe

977 Geologique de France 174, 357-371.

978

979 Ferrandini, M., Ferrandini, J., Loÿe-Pilot, M.-D., Butterlin, J., Cravatte, J. \& Janin, M.-C.

980 (1998). Le Miocène du bassin de Saint-Florent (Corse): Modalités de la transgression du

981 Burdigalien supérieur et mise en évidence du Serravallien. Geobios 31, 125-137.

982

983 Fournier, M., Jolivet, L., Goffé, B. \& Dubois, R. (1991). Alpine Corsica Metamorphic Core

984 Complex. Tectonics 10, 1173-1186.

985

986 Garfagnoli, F., Menna, F., Pandeli, E. \& Principi, G. (2009). Alpine metamorphic and tectonic

987 evolution of the Inzecca-Ghisoni area (southern Alpine Corsica, France). Geological Journal $988 \quad 44,191-210$.

989

990 Gibbons, W. \& Horak, J. (1984). Alpine metamorphim of Hercynian hornblende granodiorite

991 beneath the blueschist facies schistes-lustrés nappe of NE Corsica. Journal of Metamorphic 992 Geology 2, 95-113. 
994 Goncalves, P., Oliot, E., Marquer, D. \& Connolly, J. A. D. (2012). Role of chemical processes 995 on shear zone formation: an example from the Grimsel metagranodiorite (Aar massif, Central 996 Alps). Journal of Metamorphic Geology 30.

997

998 Goncalves, P., Poilvet, J.-C., Oliot, E., Trap, P. \& Marquer, D. (2016). How does shear zone 999 nucleate? An example from the Suretta nappe (Swiss Eastern Alps). Journal of Structural 1000 Geology 86, 166-180.

1001

1002 Gueguen, E., Doglioni, C. \& Fernandez, M. (1998). On the post-25 Ma geodynamic evolution 1003 of the western Mediterranean. Tectonophysics 298, 259-269.

1004

1005 Gueydan, F., Leroy, Y. M., Jolivet, L. \& Agard, P. (2003). Analysis of continental midcrustal 1006 strain localization induced by microfracturing and reaction-softening. Journal of Geophysical 1007 Research 108, 2064.

1008

1009 Huet, B., Labrousse, L. \& Jolivet, L. (2009). Thrust or detachment? Exhumation processes in 1010 the Aegean: Insight from a field study on Ios (Cyclades, Greece). Tectonics 28, TC3007.

1011

1012 Ingles, J., Lamouroux, C., Soula, J.-C., Guerrero, N. \& Debat, P. (1999). Nucleation of ductile 1013 shear zones in a granodiorite under greenschist facies conditions, Néouvielle massif, 1014 Pyrenees, France. Journal of Structural Geology 21, 555-576.

1015

1016 Jakni, B., Poupeau, G., Sosson, M., Rossi, P., Ferrandini, J. \& Guennoc, P. (2000). 1017 Dénudations cénozoïques en Corse $\square$ : une analyse thermochronologique par traces de fission 1018 sur apatites. Comptes Rendus de l'Academie des Sciences de Paris 331, 775-782. 
1020 Jolivet, L. et al. (1998). Midcrustal shear zones in postorogenic extension: Example from the 1021 northern Tyrrhenian Sea. Journal of Geophysical Research 103, 12123-12160.

1022

1023 Jolivet, L., Augier, R., Faccenna, C., Negro, F., Rimmelé, G., Agard, P., Robin, C., Rossetti, 1024 F. \& Crespo-Blanc, A. (2008). Subduction, convergence and the mode of backarc extension in 1025 the Mediterranean region. Bulletin de la Societe Geologique de France 179, 525-550.

1026

1027 Jolivet, L., Daniel, J. M. \& Fournier, M. (1991). Geometry and kinematics of extension in 1028 Alpine Corsica. Earth and Planetary Science Letters 104, 278-291.

1029

1030 Jolivet, L., Dubois, R., Fournier, M., Goffé, B., Michard, A. \& Jourdan, C. (1990). Ductile extension in alpine Corsica. Geology 18, 1007-1010.

1032

1033 Jolivet, L., Gorini, C., Smit, J. \& Leroy, S. (2015). Continental breakup and the dynamics of 1034 rifting in back-arc basins: The Gulf of Lion margin. Tectonics 34, 662-679.

1035

Jourdan, C. (1988). Balagne orientale et massif du Tenda (Corse septentrionale): étude 1037 structurale, interprétation des accidents et des déformations, reconstitutions géodynamiques.

1038 Thèse de Doctorat, Orsay, Université de Paris-Sud.

1039

1040 Lacombe, O. \& Jolivet, L. (2005). Structural and kinematic relationships between Corsica and 1041 the Pyrenees-Provence domain at the time of the Pyrenean orogeny. Tectonics 24, TC1003. 
1043 Lahondère, D. (1988). Le métamorphisme éclogitique dans les orthogneiss et les métabasites

1044 ophiolitiques de la région de Farinole (Corse). Bulletin de la Societe Geologique de France 4, $1045 \quad 579-585$.

1046

1047 Lahondère, D. \& Guerrot, C. (1997). Datation Sm-Nd du métamorphisme éclogitique en 1048 Corse alpine $\square$ : un argument pour l'existence au Crétacé supérieur d'une zone de subduction 1049 active localisée sous le bloc corso-sarde. Géologie de la France 3, 3-11.

1050

1051 Launeau, P. \& Robin, P.-Y. F. (2005). Determination of fabric and strain ellipsoids from 1052 measured sectional ellipses - implementation and applications. Journal of Structural Geology $105327,2223-2233$.

1054

1055 Laurent, V., Beaudoin, A., Jolivet, L., Arbaret, L., Augier, R., Rabillard, A. \& Menant, A. 1056 (2015). Interrelations between extensional shear zones and synkinematic intrusions: The 1057 example of Ikaria Island (NE Cyclades, Greece). Tectonophysics 651-652, 152-171.

1058

1059 Leloup, P. H., Arnaud, N., Sobel, E. R. \& Lacassin, R. (2005). Alpine thermal and structural 1060 evolution of the highest external crystalline massif: The Mont Blanc. Tectonics 24, TC4002.

1061

1062 Maffione, M., Speranza, F., Faccenna, C., Cascella, A., Vignaroli, G. \& Sagnotti, L. (2008). A 1063 synchronous Alpine and Corsica-Sardinia rotation. Journal of Geophysical Research 113, 1064 B03104.

1065

1066 Maggi, M., Rossetti, F., Corfu, F., Theye, T., Andersen, T. B. \& Faccenna, C. (2012). 1067 Clinopyroxene-rutile phyllonites from the East Tenda Shear Zone (Alpine Corsica, France): 
pressure-temperature-time constraints to the Alpine reworking of Variscan Corsica. Journal of

1069 the Geological Society 169, 723-732.

1070

1071 Maggi, M., Rossetti, F., Ranalli, G. \& Theye, T. (2014). Feedback between fluid infiltration 1072 and rheology along a regional ductile-to-brittle shear zone: The East Tenda Shear Zone 1073 (Alpine Corsica). Tectonics 33, 253-280.

1074

Malasoma, A. \& Marroni, M. (2007). HP/LT metamorphism in the Volparone Breccia (Northern Corsica, France): evidence for involvement of the Europe/Corsica continental

1077 margin in the Alpine subdution zone. Journal of Metamorphic Geology 25, 529-545.

1078

Malasoma, A., Marroni, M., Musumeci, G. \& Pandolfi, L. (2006). High-pressure mineral 1080 assemblage in granitic rocks from continental units, Alpine Corsica, France. Geological Journal 41, 49-59.

1082

1083 Malavieille, J., Chemenda, A. \& Larroque, C. (1998). Evolutionary model for Alpine Corsica: 1084 mechanism for ophiolite emplacement and exhumation of high-pressure rocks. Terra Nova 10, $1085 \quad 317-322$.

1086

1087 Malinverno, A. \& Ryan, W. B. F. (1986). Extension in the Tyrrhenian Sea and shortening in 1088 the Apennines as result of arc migration driven by sinking of the lithosphere. Tectonics 5, $1089227-245$. 
1091 Malusà, M. G. et al. (2015). Contrasting styles of (U)HP rock exhumation along the Cenozoic

1092 Adria-Europe plate boundary (Western Alps, Calabria, Corsica). Geochemistry Geophysics 1093 Geosystems 16, 1786-7824.

1094

1095 Maluski, H. (1977). Application de la méthode 40Ar/39Ar aux minéraux des roches 1096 cristallines perturbées par les événements thermiques et tectoniques en Corse. Bulletin de la 1097 Societe Geologique de France 19, 849-855.

1098

1099 Mancktelow, N. S. \& Pennacchioni, G. (2005). The control of precursor brittle fracture and 1100 fluid-rock interaction on the development of single and paired ductile shear zones. Journal of 1101 Structural Geology 27, 645-661.

1102

1103 Martin, L. A. J., Rubatto, D., Brovarone, A. V. \& Hermann, J. (2011). Late Eocene lawsonite-

1104 eclogite facies metasomatism of a granulite sliver associated to ophiolites in Alpine Corsica. 1105 Lithos 125, 620-640.

1106

1107 Mattauer, M., Faure, M. \& Malavieille, J. (1981). Transverse lineation and large-scale 1108 structures related to Alpine obduction in Corsica. Journal of Structural Geology 3, 401-409.

1109

1110 Meresse, F., Lagabrielle, Y., Malavieille, J. \& Ildefonse, B. (2012). A fossil Ocean-Continent

1111 Transition of the Mesozoic Tethys preserved in the Schistes Lustrés nappe of northern 1112 Corsica. Tectonophysics 579, 4-16. 
1114 Molli, G. (2008). Northern Apennine-Corsica orogenic system: an updated overview. In:

1115 Siegesmund, S., Fügenschuh, B., Froitzheim, N. (Eds.), Tectonic Aspects of the Alpine-

1116 Dinaride-Carpathian System. Geological Society, London, Special Publications 298, 413-442.

1118 Molli, G. \& Malavieille, J. (2011). Orogenic processes and the Corsica/Apennines 1119 geodynamic evolution: insights from Taiwan. International Journal of Earth Sciences 100, $1120 \quad 1207-1224$.

1122 Molli, G. \& Tribuzio, R. (2004). Shear zones and metamorphic signature of subducted

1123 continental crust as tracers of the evolution of the Corsica/Northern Apennine orogenic 1124 system. Geological Society, London, Special Publications 224, 321-335.

1125

1126 Molli, G., Tribuzio, R. \& Marquer, D. (2006). Deformation and metamorphism at the eastern

1127 border of the Tenda Massif (NE Corsica): a record of subduction and exhumation of 1128 continental crust. Journal of Structural Geology 28, 1748-1766.

1130 Mouthereau, F., Tensi, J., Bellahsen, N., Lacombe, O., De Boisgrollier, T. \& Kargar, S. 1131 (2007). Tertiary sequence of deformation in a thin-skinned/thick-skinned collision belt: The 1132 Zagros Folded Belt (Fars, Iran). Tectonics 26, TC5006.

1134 Mouthereau, F., Watts, A. B. \& Burov, E. (2013). Structure of orogenic belts controlled by 1135 lithosphere age. Nature Geoscience 6, 785-789. 
1137 Ohnenstetter, M., Ohnenstetter, D., Vidal, P., Cornichet, J., Hermitte, D. \& Mace, J. (1981).

1138 Crystallization and age of zircon from Corsican ophiolitic albitites: consequences for oceanic 1139 expansion in Jurassic times. Earth and Planetary Science Letters 54, 397-408.

1140

1141 Oliot, E., Goncalves, P. \& Marquer, D. (2010). Role of plagioclase and reaction softening in a 1142 metagranite shear zone at mid-crustal conditions (Gotthard Massif, Swiss Central Alps).

1143 Journal of Metamorphic Geology 28, 849-871.

1144

1145 Oliot, E., Goncalves, P., Schulmann, K., Marquer, D. \& Lexa, O. (2014). Mid-crustal shear 1146 zone formation in granitic rocks: Constraints from quantitative textural and crystallographic 1147 preferred orientations analyses. Tectonophysics $612-613,63-80$.

1149 Oudet, J., Münch, P., Borgomano, J., Quillevere, F., Melinte-Dobrinescu, M. C., Demory, F.,

1150 Viseur, S. \& Cornee, J.-J. (2010). Land and sea study of the northeastern golfe du Lion rifted 1151 margin: the Oligocene-Miocene of southern Provence (Nerthe area, SE France). Bulletin de la 1152 Société géologique de France 181, 591-607.

1153

1154 Pennacchioni, G. \& Mancktelow, N. S. (2007). Nucleation and initial growth of a shear zone 1155 network within compositionally and structurally heterogeneous granitoids under amphibolite 1156 facies conditions. Journal of Structural Geology 29, 1757-1780.

1158 Raimbourg, H., Jolivet, L., Labrousse, L., Leroy, Y. \& Avigad, D. (2005). Kinematics of 1159 syneclogite deformation in the Bergen Arcs, Norway: implications for exhumation 1160 mechanisms. In: Gapais, D., Brun, J. P., Cobbold, P. R. (Eds.), Deformation Mechanisms, 
1161 Rheology and Tectonics: from Minerals to the Lithosphere. Geological Society, London,

1162 Special Publications 243, 175-192.

1163

1164 Ravna, E. J. K., Andersen, T. B., Jolivet, L. \& De Capitani, C. (2010). Cold subduction and

1165 the formation of lawsonite eclogite - constraints from prograde evolution of eclogitized

1166 pillow lava from Corsica. Journal of Metamorphic Geology 28, 381-395.

1167

1168 Rehault, J.-P., Boillot, G. \& Mauffret, A. (1984). The Western Mediterranean Basin 1169 geological evolution. Marine Geology 55, 447-477.

1170

1171 Rennie, S. F., Fagereng, A. \& Diener, J. F. A. (2013). Strain distribution within a km-scale,

1172 mid-crustal shear zone: The Kuckaus Mylonite Zone, Namibia. Journal of Structural Geology $117356,57-69$.

1174

1175 Rossetti, F., Faccenna, C., Goffé, B., Monié, P., Argentieri, A., Funiciello, R. \& Mattei, M.

1176 (2001). Alpine structural and metamorphic signature of the Sila Piccola Massif nappe stack

1177 (Calabria, Italy): Insights for the tectonic evolution of the Calabrian Arc. Tectonics 20, 1121178133.

1179

1180 Rossetti, F., Glodny, J., Theye, T. \& Maggi, M. (2015). Pressure-temperature-deformation-

1181 time of the ductile Alpine shearing in Corsica: From orogenic construction to collapse. Lithos $1182 \quad 218-219,99-116$.

1183

1184 Rossi, P. et al. (2001). Carte Géologique de France (1/50 000), feuille de Santo-Pietro-Di-

1185 Tenda (1106). Bureau des Recherches Géologiques et Minières. 
1187 Rossi, P., Durand-Delga, M. \& Cocherie, A. (1993). Caractère volcano-plutonique du 1188 magmatisme calco-alcalin composite d'âge Stéphanien supérieur-Permien inférieur en Corse. 1189 Comptes Rendus de l'Academie des Sciences de Paris 316, 1779-1788.

1190

1191 Rossi, P., Lahondère, J.-C., Lluch, D., Loÿe-Pilot, M.-D. \& Jacquet, M. (1994). Carte

1192 Géologique de France (1/50 000), feuille de Saint-Florent (1103). Bureau des Recherches 1193 Géologiques et Minières.

1194

1195 Séranne, M. (1999). The Gulf of Lion continental margin (NW Mediterranean) revisited by 1196 IBS: an overview. In: Durand, B., Jolivet, L., Horvath, F., Séranne, M. (Eds.), Tertiary 1197 Extension within the Alpine Orogen. Geological Society, London, Special Publications 156, $1198 \quad 15-36$.

1199

1200 Speranza, F., Villa, I. M., Sagnotti, L., Florindo, F., Cosentino, D., Cipollari, P. \& Mattei, M. 1201 (2002). Age of the Corsica-Sardinia rotation and Liguro-Provençal Basin spreading: new 1202 paleomagnetic and Ar/Ar evidence. Tectonophysics 347, 231-251.

1203

1204 Sullivan, W. A., Boyd, A. S. \& Monz, M. E. (2013). Strain localization in homogeneous 1205 granite near the brittle-ductile transition: A case study of the Kellyland fault zone, Maine, 1206 USA. Journal of Structural Geology 56, 70-88.

1207

1208 Tribuzio, R. \& Giacomini, F. (2002). Blueschist facies metamorphism of peralkaline rhyolites 1209 from the Tenda crystalline massif (northern Corsica): evidence for involvement in the Alpine 1210 subduction event? Journal of Metamorphic Geology 20, 513-526. 
1212 Vitale Brovarone, A., Beltrando, M., Malavieille, J., Giuntoli, F., Tondella, E., Groppo, C.,

1213 Beyssac, O. \& Compagnoni, R. (2011a). Inherited Ocean-Continent Transition zones in 1214 deeply subducted terranes: Insights from Alpine Corsica. Lithos 124, 273-290.

1215

1216 Vitale Brovarone, A., Beyssac, O., Malavieille, J., Molli, G., Beltrando, M. \& Compagnoni, 1217 R. (2013). Stacking and metamorphism of continuous segments of subducted lithosphere in a 1218 high-pressure wedge: The example of Alpine Corsica (France). Earth-Science Reviews 116, $1219 \quad 35-56$.

1220

1221 Vitale Brovarone, A., Groppo, C., Hetényi, G., Compagnoni, R. \& Malavieille, J. (2011b).

1222 Coexistence of lawsonite-bearing eclogite and blueschist: phase equilibria modelling of 1223 Alpine Corsica metabasalts and petrological evolution of subducting slabs. Journal of 1224 Metamorphic Geology 29, 583-600.

1226 Vitale Brovarone, A. V. \& Herwartz, D. (2013). Timing of HP metamorphism in the Schistes 1227 Lustres of Alpine Corsica: New Lu-Hf garnet and lawsonite ages. Lithos 172, 175-191.

1228

1229 Zarki-Jakni, B., van der Beek, P., Poupeau, G., Sosson, M., Labrin, E., Rossi, P. \& Ferrandini,

1230 J. (2004). Cenozoic denudation of Corsica in response to Ligurian and Tyrrhenian extension:

1231 Results from apatite fission track thermochronology. Tectonics 23, TC1003.

1232

1233

Figures Captions

1234 
1235 Figure 1. Geological map of the studied area. (a) Tectonic map of western Mediterranean

1236

1237

1238

1239

1240

1241

1242

1243

1244

1245

1246

1247

1248

1249

1250

1251

1252

1253

1254

1255

1256

1257

1258

1259 region. (b) Geological map of Alpine Corsica associated with a representative cross-section (modified after Vitale Brovarone et al., 2013). Ce: Centuri continental unit; Fa: Farinole continental unit; In: Inzecca unit; Ma: Macinaggio unit; Ne: Nebbio unit; Sa: Sampolo unit; SDP: Serra di Pigno continental unit; SL: Santa Lucia; Pi: Pineto ophiolitic unit; Po: Popolasca unit.

Figure 2. Simplified geological map (modified after Rossi et al., 1994; 2001) with main planar fabrics of the Tenda massif. (a) Foliation map. (b) $S_{2}$ trajectories map. Note that $S_{2}$ depicts anastomosing structures around grey zones that represent volumes where $S_{1}$ or even undeformed rocks are preserved. (c) Statistics of the foliations geometries. Foliation poles are presented with density contours in Schmidt's lower hemisphere equal-area projection and strike preferred orientations are given by rose-diagrams. Geometries of the large-scale were retrieved by the SW-NE elongation of the clouds showing a NW-SE dome. $\mathrm{S}_{1}$ and $\mathrm{S}_{2}$ strikes are characterized by different preferred orientations from $\mathrm{N} 170^{\circ} \mathrm{E}$ to $\mathrm{N} 140^{\circ} \mathrm{E}$, respectively. Note that the $S_{2}$ dip is relatively flat comparing to $S_{1}$ that displays more dispersed dips from flat to vertical.

Figure 3. Characterization of the main planar fabrics and folds at different scales. (a) Subvertical $S_{1}$ of the Mt Genova (view from the south). (b) Close-up view of $\mathrm{D}_{2}$ folds affecting $S_{1}$ and associated with the development of a $S_{2}$ crenulation cleavage in the center of the Tenda massif $\left(\mathrm{N} 42.654838^{\circ} \mathrm{E} 9.190533^{\circ}\right)$. (c) Close-up view of $\mathrm{D}_{2}$ folds and folded $\mathrm{S}_{1}$ associated with the development of a $S_{2}$ crenulation cleavage in the lowermost structural levels of the ETSZ $\left(\mathrm{N} 42.640269^{\circ} \mathrm{E} 9.264771^{\circ}\right)$. Note that $\mathrm{S}_{1}$ carries blue-amphibole formed during $\mathrm{D}_{1}$. (d) Microscopic view from the previous outcrop (insert c). Note that $\mathrm{S}_{1}$ carries 
1260 blue-amphiboles that are retrogressed into chlorite in $S_{2}$ cleavage. (e) Equal-area projection 1261 plots (Schmidt's lower hemisphere) of structural features characterizing $\mathrm{D}_{2}$ folds from typical 1262 outcrops over the Tenda massif: Envelopes of folded $S_{1}$ are steeply dipping while $S_{2}$ is sub1263 horizontal, both striking NNW-SSE, just as the $\mathrm{D}_{2}$ fold axis trends.

1265 Figure 3 (continued). (f and g) Landscape views of the Saleccia Shear Zone (SSZ) (f: view 1266 from the main D81 road) and the ETSZ (g: view from the Punta Mortella) both marked by the 1267 development of a penetrative $S_{2}$ fabric. $S_{2}$ planes from the SSZ and the ETSZ are plotted. (h)

1268 Late $\mathrm{D}_{2}$ folds affecting $\mathrm{S}_{2}$ in the Punta Mortella (N $42.718401^{\circ}$ E 9.250547 $)$. (i) Equal-area 1269 projection plots (Schmidt's lower hemisphere) of late $\mathrm{D}_{2}$ folds axis of the ETSZ from Punta di 1270 Cepo to Punta Mortella. Note that axis trends evolve from NNW-SSE away from the ETSZ 1271 (Fig. 3e) to ENE-WSW near its most deformed parts.

1273 Figure 4. Stretching lineations of the Tenda massif. (a) Stretching lineation map and 1274 associated sense of shear. (b) Statistics of the stretching lineations geometries. Lineation poles 1275 are presented with density contours in Schmidt's lower hemisphere equal-area projection and 1276 trends preferred orientations are given by rose-diagrams. Note that $\mathrm{L}_{1}$ and $\mathrm{L}_{2}$ trends are 1277 characterized by slightly different preferred orientations from $\mathrm{N} 063^{\circ} \mathrm{E}$ to $\mathrm{N} 052^{\circ} \mathrm{E}$, 1278 respectively.

1280 Figure 5. Kinematics of $\mathrm{D}_{2}$ deformation in the whole Tenda massif. (a) Representative cross 1281 section of the Tenda massif from west to east showing the large-scale structures and the 1282 geometries of $\mathrm{D}_{2}$ top-to-the-NE (green) and $\mathrm{D}_{1}$ top-to-the-SW shearing (blue). Note that both $1283 \mathrm{D}_{1}$ and $\mathrm{D}_{2}$ affect the whole massif; the undeformed Variscan protolith being locally preserved. 1284 Also showed are stereographic projections of structures along the cross-section. Letters 
1285 highlight the position of pictures presented in the rest of figure 5. (b) Top-to-the-NE 1286 mylonites in the Saleccia rhyolite, west of Saleccia. (c) Localized top-to-the-NE narrow shear 1287 zone in the west of the Tenda massif $\left(\mathrm{N} 42.667220^{\circ} \mathrm{E} 9.148613^{\circ}\right)$. (d) Localized top-to-the1288 NE steep semi-brittle shear zone affecting an isotropic protolith in the ETSZ $\left(\mathrm{N} 42.650459^{\circ} \mathrm{E}\right.$ $\left.1289 \quad 9.263404^{\circ}\right)$

1291 Figure 5 (continued). (e) Rhyolite intrusion (top of a small-scale dome) asymmetrically 1292 boudinaged in a pelitic matrix, west of the Tenda massif $\left(\mathrm{N} 42.661448^{\circ} \mathrm{E} 9.130829^{\circ}\right)$. (f)

1293 Zoom on the previous outcrop: $\mathrm{D}_{2}$ folds with folded $\mathrm{S}_{1}$ associated with $\mathrm{S}_{2}$ crenulation. Note, 1294 from e and $\mathrm{f}$, that $\mathrm{S}_{2}$ is sigmoidal in between top-to-the-NE shear bands. (g) Top-to-the-NE 1295 shearing of a granitic dyke within a micaschists matrix (Punta di Mignola shear zone; contact 1296 between the volcano-sedimentary sequence and the granitic complex). (h) Blue-amphibole 1297 forming sigma-clasts compatible with top-to-the-NE shearing in the ETSZ (N $42.658489^{\circ} \mathrm{E}$ 9.272518 ${ }^{\circ}$. (i) Microscopic view in thin section from the previous outcrop. Top-to-the-NE 1299 shearing is associated with the boudinage and truncation of blue-amphibole that is 1300 retrogressed into chlorite. Note that crystallization of small blue-amphiboles in tails of sigma1301 clasts also occurs (see white square). (j) Mylonites in the uppermost levels of the ETSZ. 1302 Mineral association is made of quartz, albite, phengite, chlorite and pyrite $\left(\mathrm{N} 42.700461^{\circ} \mathrm{E}\right.$ $\left.1303 \quad 9.26382^{\circ}\right)$

1305 Figure 6. Examples of $\mathrm{D}_{1}$ top-to-the-SW criteria. $(\mathrm{a}, \mathrm{b}, \mathrm{c})$ Typical outcrop showing preserved 1306 top-to-the-SW criteria in the lowermost structural levels of the ETSZ $\left(\mathrm{N} 42.649840^{\circ} \mathrm{E}\right.$ $13079.266655^{\circ}$ ). (a) In poorly deformed zone, gently dipping top-to-the-SW localized shear bands 1308 affect an undeformed granite. Note that $S_{1}$ only develops near shear bands. (b) With 1309 increasing deformation, the outcrop is characterized by distributed strain with mylonites. Top- 
to-the-SW shear bands dip to the west when $\mathrm{S}_{1}$ appears flat. (c) Top-to-the-SW shearing

1311 appears sometimes localized through high strain bands. Note that this band widens from the

1312 left to the right of the picture. Note also that shear bands in (a) and the high strain band in (c)

1313 have the same orientation. (d) Toward the top of the ETSZ, both $\mathrm{S}_{1}$ and shear bands dip to the

1314 east, compatibly with the general trend of the ETSZ (N $42.654916^{\circ}$ E $\left.9.267789^{\circ}\right)$. Top-to-the-

1315 SW shearing is clearly recorded in the blue-amphibole stability field. (e) Cross-cutting

1316 relationships between top-to-the-NE and top-to-the-SW deformation in the ETSZ (N $\left.1317 \quad 42.656507^{\circ} \mathrm{E} 9.272097^{\circ}\right)$.

1319 Figure 7. $\mathrm{D}_{2}$ strain intensity scale in the granitic protolith. (a) Grade 0s.s: outcrop picture of a 1320 typical isotropic granite $\left(\mathrm{N} 42.67536^{\circ} \mathrm{E} 9.22939^{\circ}\right)$. The magmatic parageneses is equant and 1321 apparently metastable. (b) Grade 0s.s: magmatic hornblendes are incipiently statically 1322 replaced by blue-amphiboles involved in a coronitic reaction $\left(\mathrm{N} 42.66067^{\circ} \mathrm{E} 9.23987^{\circ}\right)$. (c)

1323 Grade 0W: top-to-the-SW shear bands and sigmodal $\mathrm{S}_{1}$ in between (N $42.649840^{\circ} \mathrm{E}$ $13249.266655^{\circ}$ ). (d) Grade 1: $\mathrm{D}_{2}$ folds with crenulated still steeply dipping $\mathrm{S}_{1}$ and formation of $\mathrm{S}_{2}$ 1325 crenulation cleavage $\left(\mathrm{N} 42.655945^{\circ} \mathrm{E} 9.272113^{\circ}\right)$. Note that deformation is characterized by 1326 only a pure shear component. (e) Grade 2: appearance of simple shear components on $\mathrm{S}_{2}$ 1327 cleavage $\left(\mathrm{N} 42.700461^{\circ} \mathrm{E} 9.26382^{\circ}\right) . \mathrm{S}_{1}$ in between shows sigmoidal feature indicating top1328 to-the-NE shearing. Angle between shear bands $\left(S_{2}\right)$ and foliation $\left(S_{1}\right)$ is about $60^{\circ}$. (f) 1329 Transition between grades 2 and 3: top-to-the-NE shear bands with sigmoidal $\mathrm{S}_{2}$ in between $1330\left(\mathrm{~N} 42.70249^{\circ} \mathrm{E} 9.25855^{\circ}\right)$. Spacing between shear bands is around 5-10 $\mathrm{cm}$. Angle between 1331 shear bands and $\mathrm{S}_{2}$ is between 60 and $30^{\circ} . \mathrm{D}_{2}$ folds remain visible. (g) Transition between 1332 grades 3 and 4: penetrative mylonitic fabric $\left(\mathrm{N} 42.700461^{\circ}\right.$ E 9.26382 $)$. Spacing between 1333 shear bands is close to $3-2 \mathrm{~cm}$, and angle between shear bands and $\mathrm{S}_{2}$ is about $30^{\circ}$. (h) Grade 
1334 4: development of ultramylonite bodies within strongly flattened mylonitic fabric (N

$\left.133542.71928^{\circ} \mathrm{E} 9.23598^{\circ}\right)$. See text for further explanations.

1337 Figure 8. Synoptic view of all strain grades described in figure 7 along a virtual $\mathrm{D}_{2}$ strain 1338 gradient. This gradient is characterized by an increase of $\mathrm{D}_{2}$ fabrics resulting in the 1339 progressive overprint of $D_{1}$ structures. Note that both spacing between shear bands and angle

1340 between $S_{2}$ and top-to-the-NE shear bands decrease upward, from grade 2 to grade 4 . Note 1341 that $D_{1}$ fabrics have always been observed at the base of the $D_{2}$ strain gradient in close 1342 association with undeformed rocks.

1344 Figure 9. Examples of structural evidence of the time-sequence relative to the increasing 1345 strain intensity. Volumes characterized by grade 2 are asymmetrically boudinaged in volumes 1346 characterized by grade 3 at outcrop (a: $\mathrm{N} 42.659128^{\circ} \mathrm{E} 9.273212^{\circ}$ ) and landscape-scales (b: $\mathrm{N}$ $\left.1347 \quad 42.71167^{\circ} \mathrm{E} 9.255127^{\circ}\right)$.

1349 Figure 10. Strain grades map of the Tenda massif within granitic protoliths. One of the five 1350 grades (see Figs. 7 and 8) has been attributed for each of the 617 visited outcrops. 1351 Interpolation highlights either the overall increase of finite deformation toward the ETSZ and 1352 the SSZ or more local strain localization. (b) Cross-sections normal to the regional foliation 1353 and parallel to the regional stretching across the main gradients of deformation. SSZ: Saleccia 1354 Shear zone; ETSZ: East Tenda Shear Zone.

1356 Figure 11. Available biostratigraphic and radiochronologic age constraints of Alpine events 1357 for the Gulf of Lion basin and Corsica-Sardinia continental portions. Data are from (1) 1358 Séranne, 1999; Oudet et al., 2010; Jolivet et al., 2015; (2) Faccenna et al., 2002; (3) Speranza 
et al., 2002; (4) Bonnal et al., 1973; Bezert and Caby, 1988; Jourdan, 1988; Egal and Caron, 1989; (5) Ferrandini et al., 2003; (6) Cavazza et al., 2007; (7) Brunet et al., 2000; (8) Martin et al., 2011; (9) Vitale Brovarone and Herwartz, 2013; (10) Rossetti et al., 2015; (11) Fellin et al., 2006; (12) Jakni et al., 2000; Zarkni-Jakni et al., 2004; (13) Lahondère and Guerrot, 1997; (14) Maggi et al., 2012; (15) Di Vincenzo et al., 2016.

Figure 12. Tectonic model of Alpine Corsica orogenic system from Eocene to Miocene (inspired from Ravna et al., 2010; Molli and Malavieille, 2011; Vitale Brovarone et al., 2013 and references on chronological constraints presented in Fig. 11) showing the evolution of deformation in the Tenda massif from burial to exhumation. During Late Eocene, the Tenda massif was buried underneath the Ligurian accretionary complex until its juxtaposition below the Schistes Lustrés nappe, and affected by top-to-the-SW deformation $\left(\mathrm{D}_{1}\right)$ firstly localized then pervasive at maximal depth. There, the two units are tectonically coupled (see also Molli et al., 2006). From Middle Oligocene to Miocene, syn-to post-orogenic exhumation was marked by a progressive localization of strain from distributed (pervasive $\mathrm{D}_{2}$ folding of previous structures) to localized notably near the ETSZ. All sketches are oriented SW-NE. 


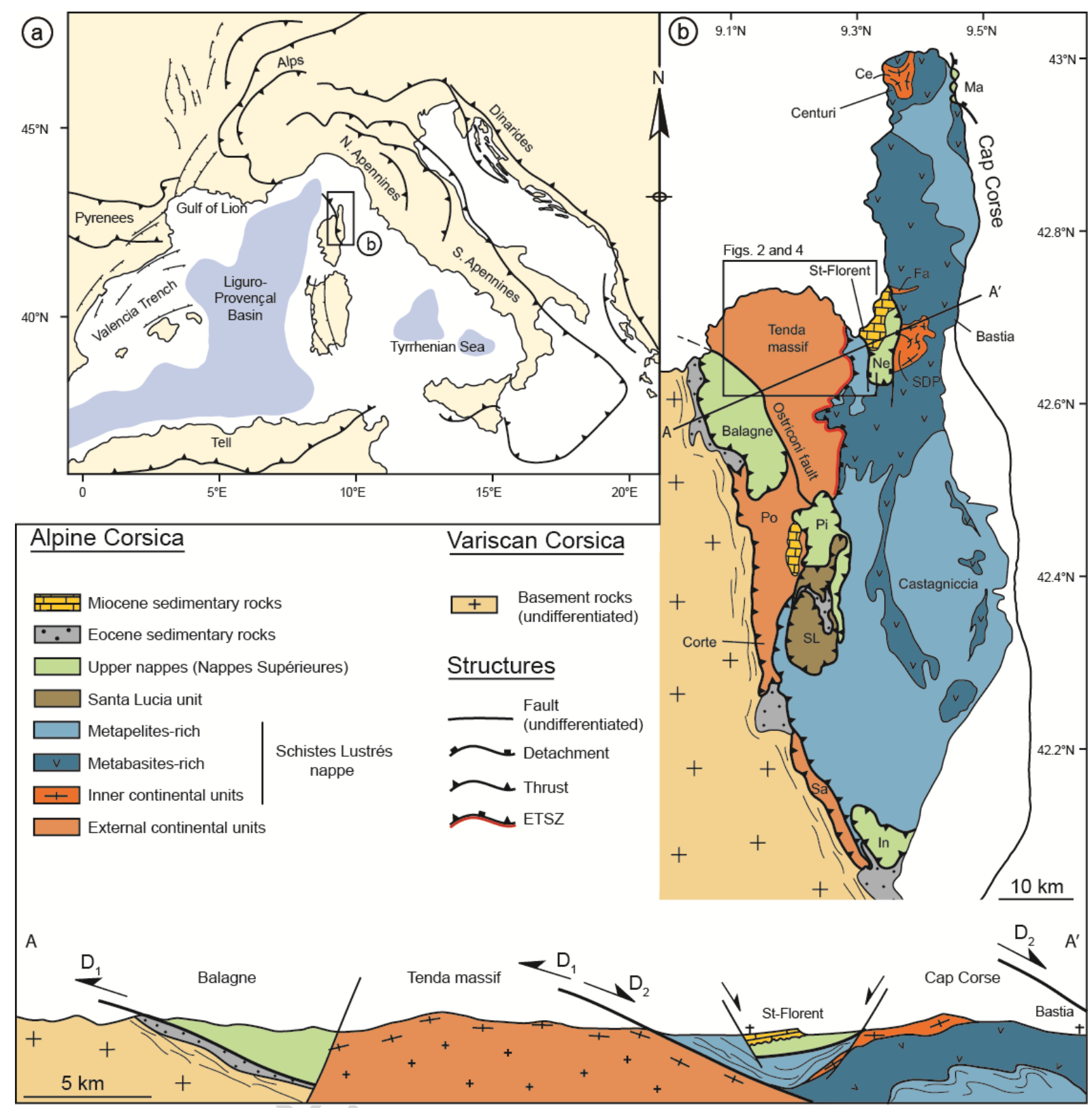

1378 Figure 1 


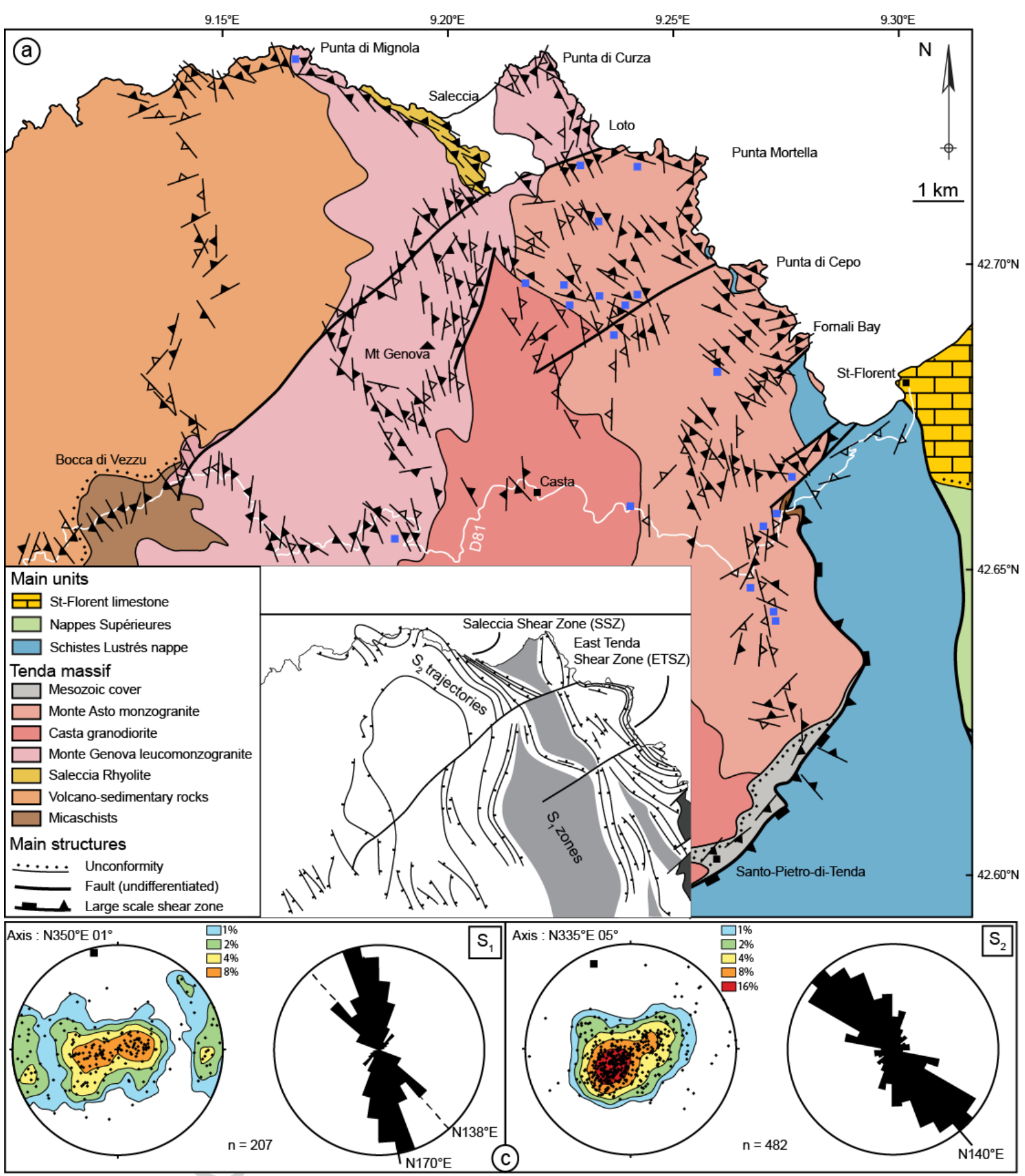

1382 Figure 2

1383 


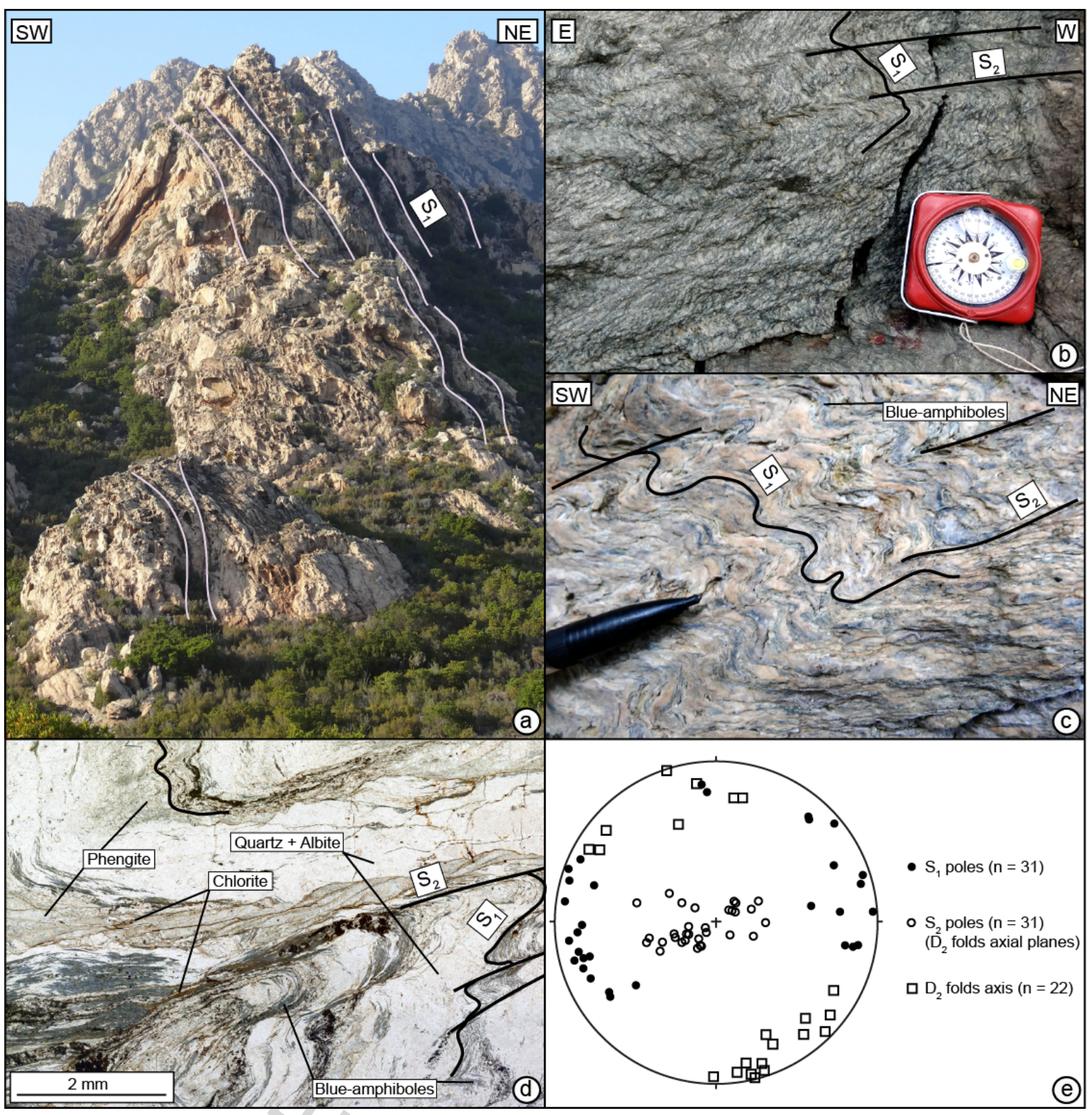

1385

1386 Figure 3-1

1387 


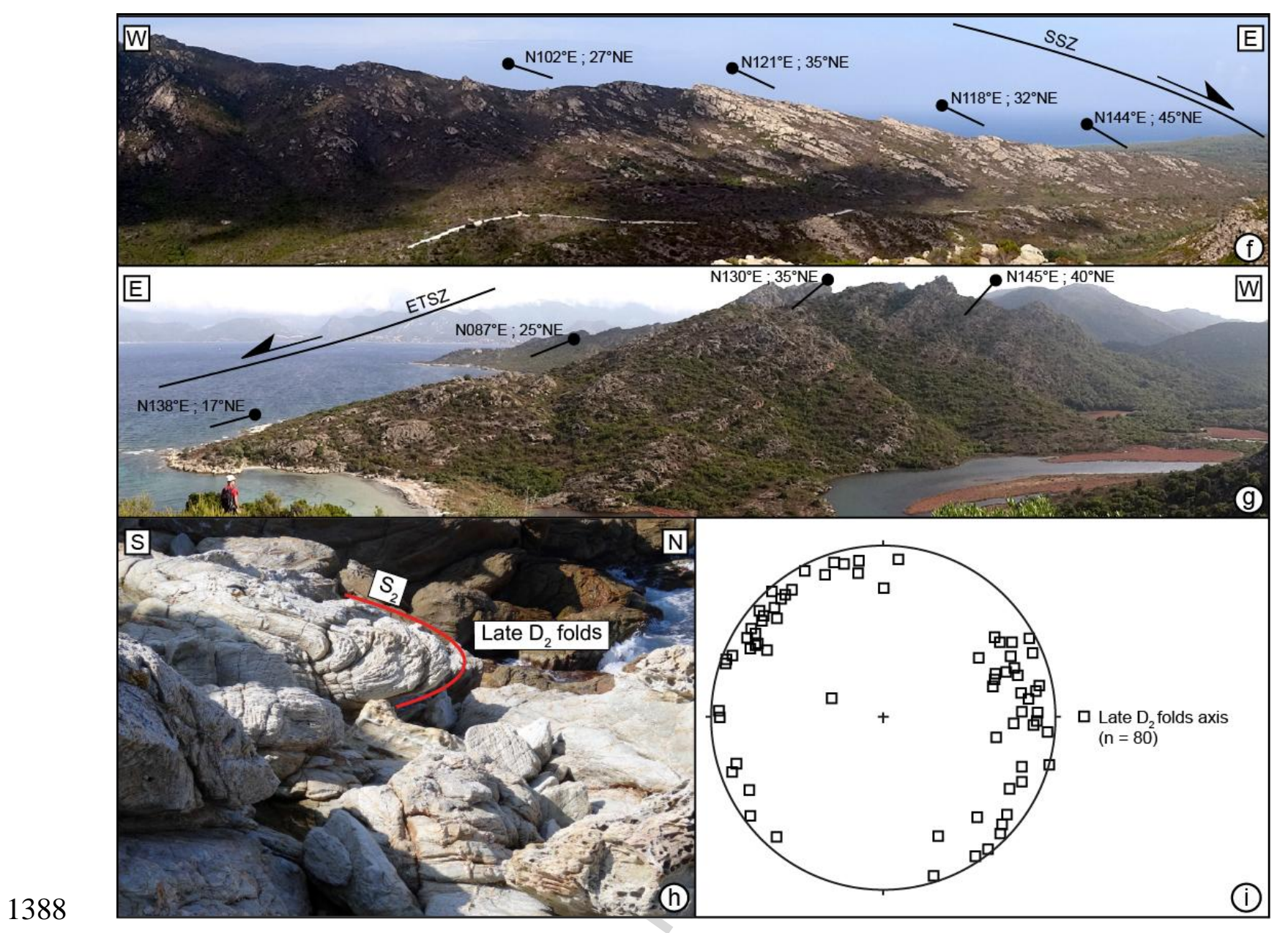

1389

1390 Figure 3-2

1391

1392 


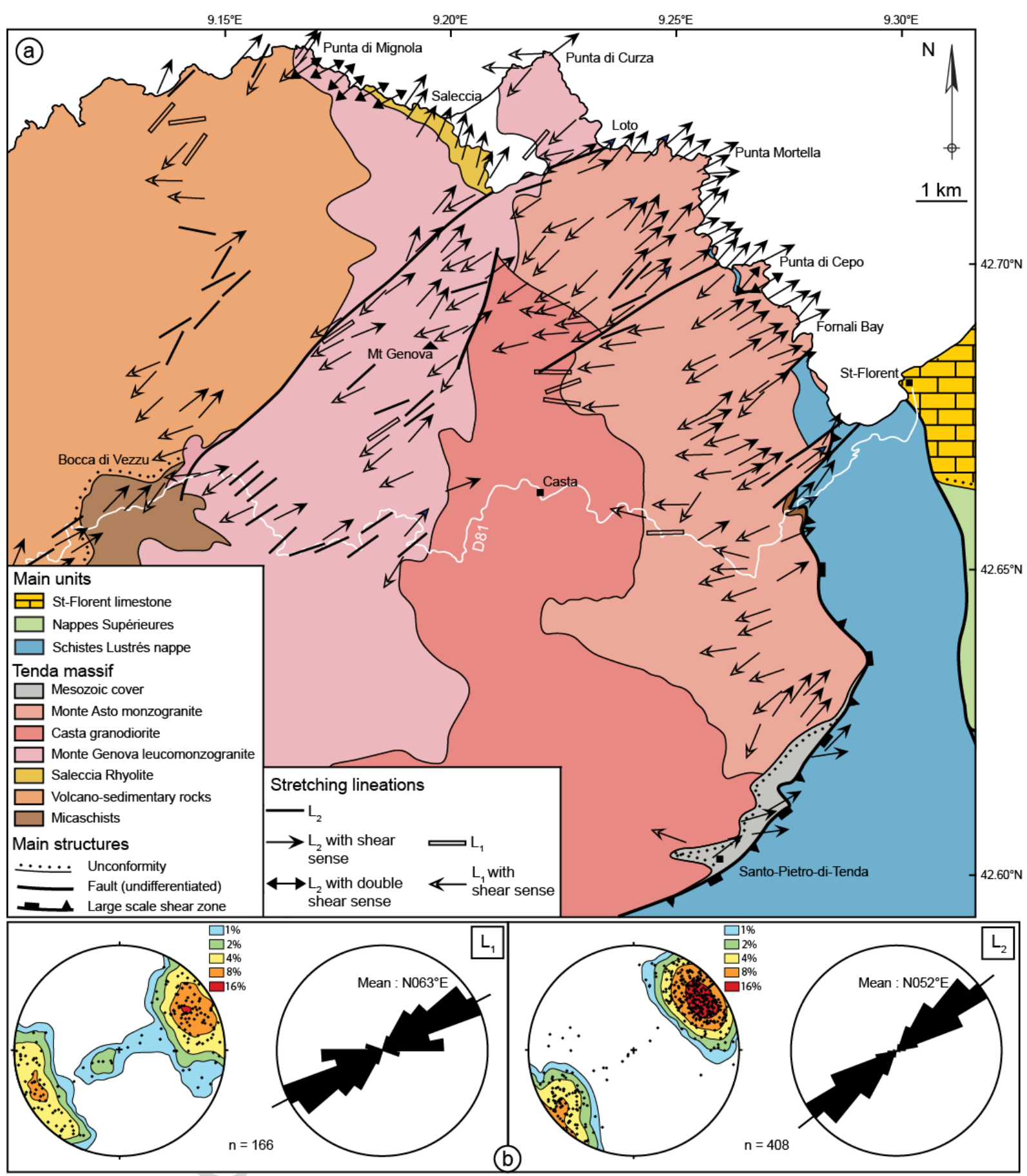

1395 Figure 4 


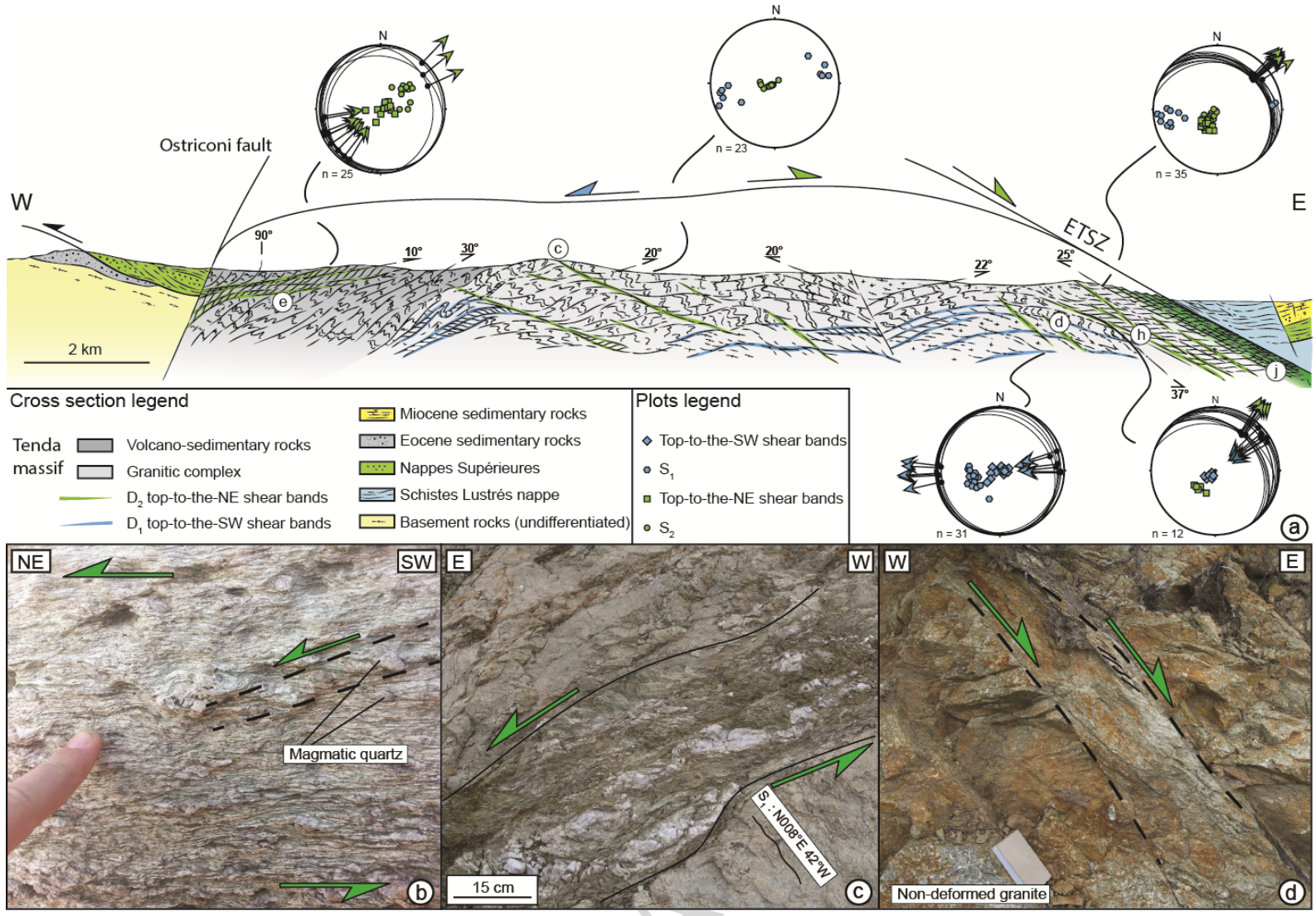

1398

1399 Figure 5-1

1400 


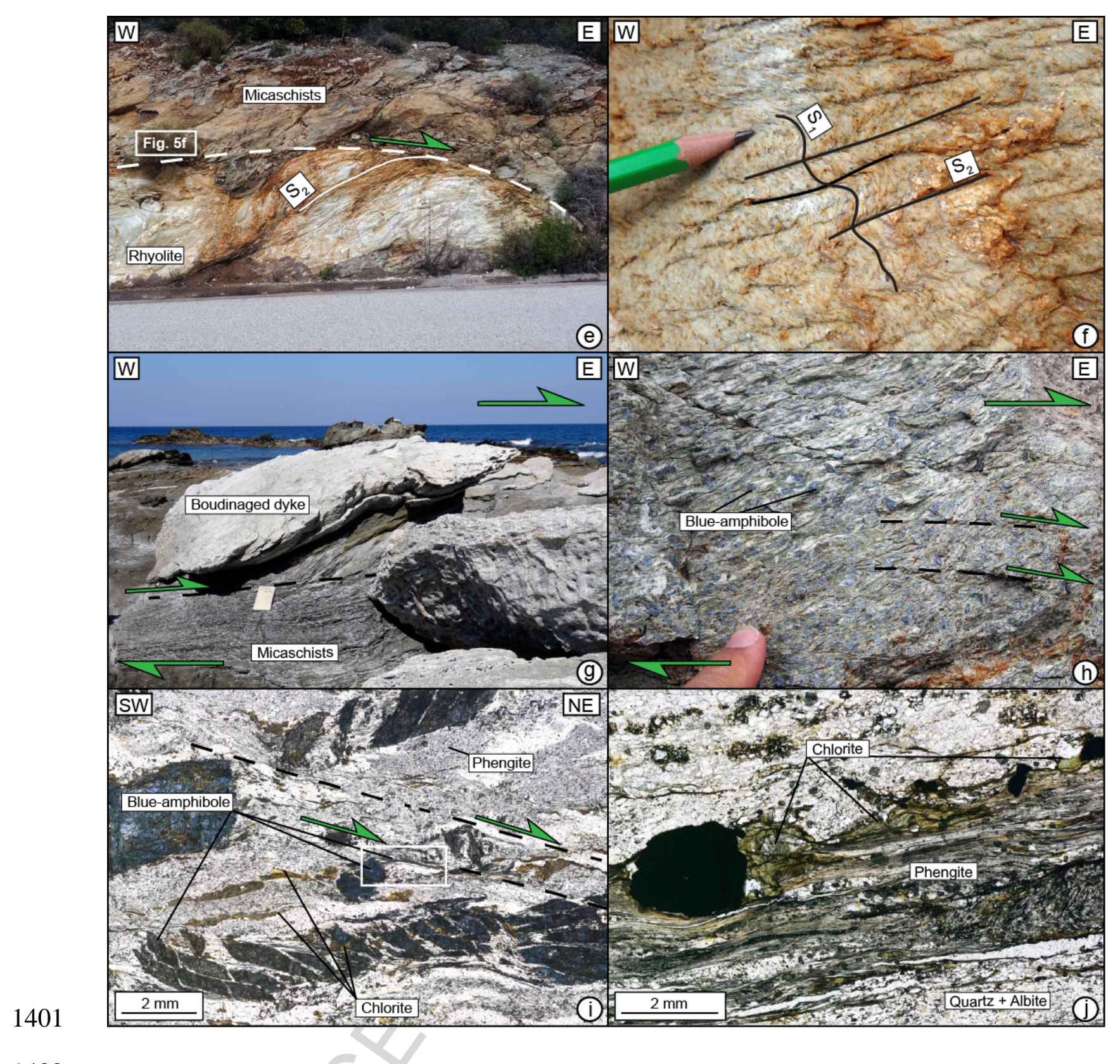

1402

1403 Figure 5-2

1404 


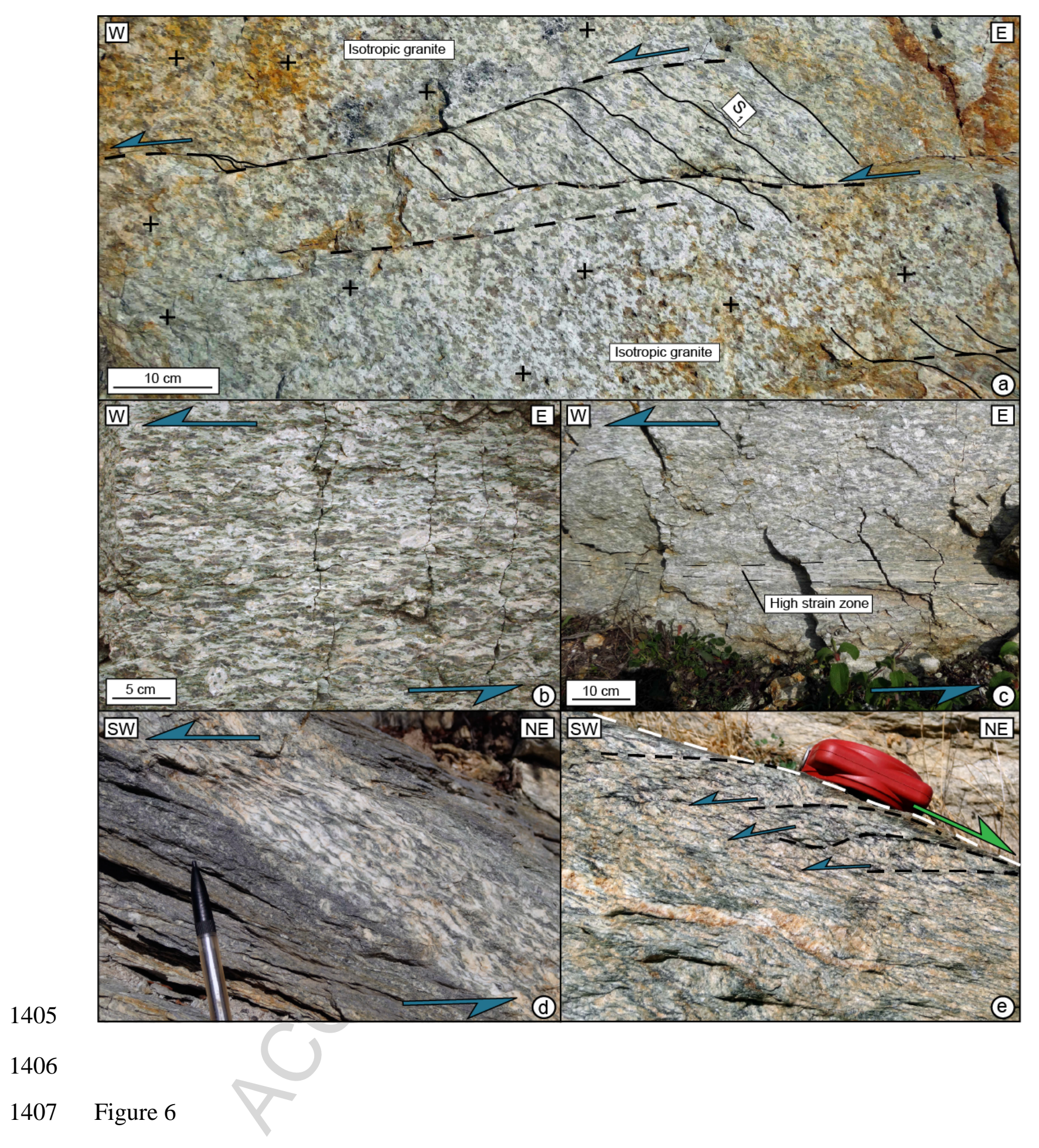

1408 


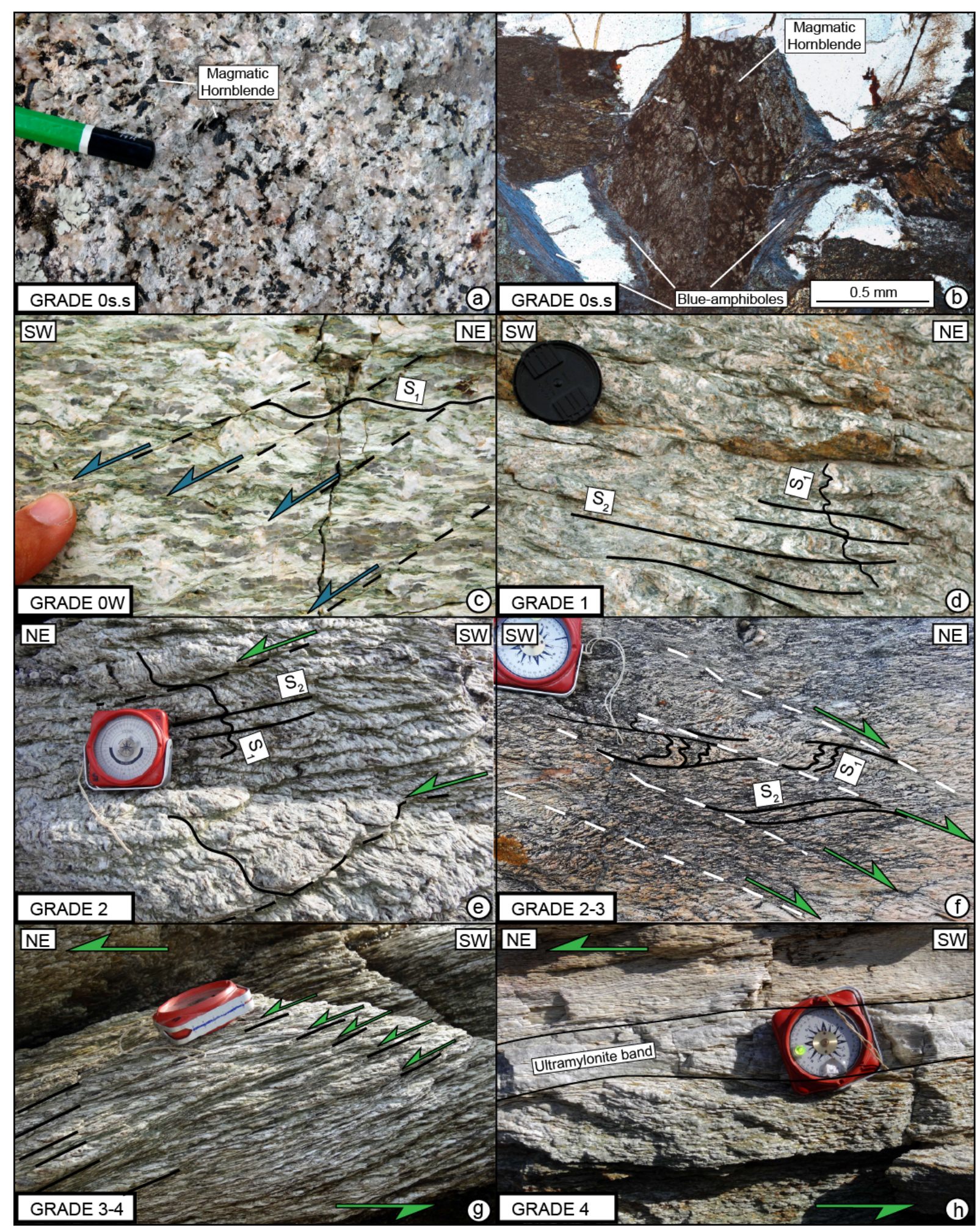

1410

1411 Figure 7

1412 


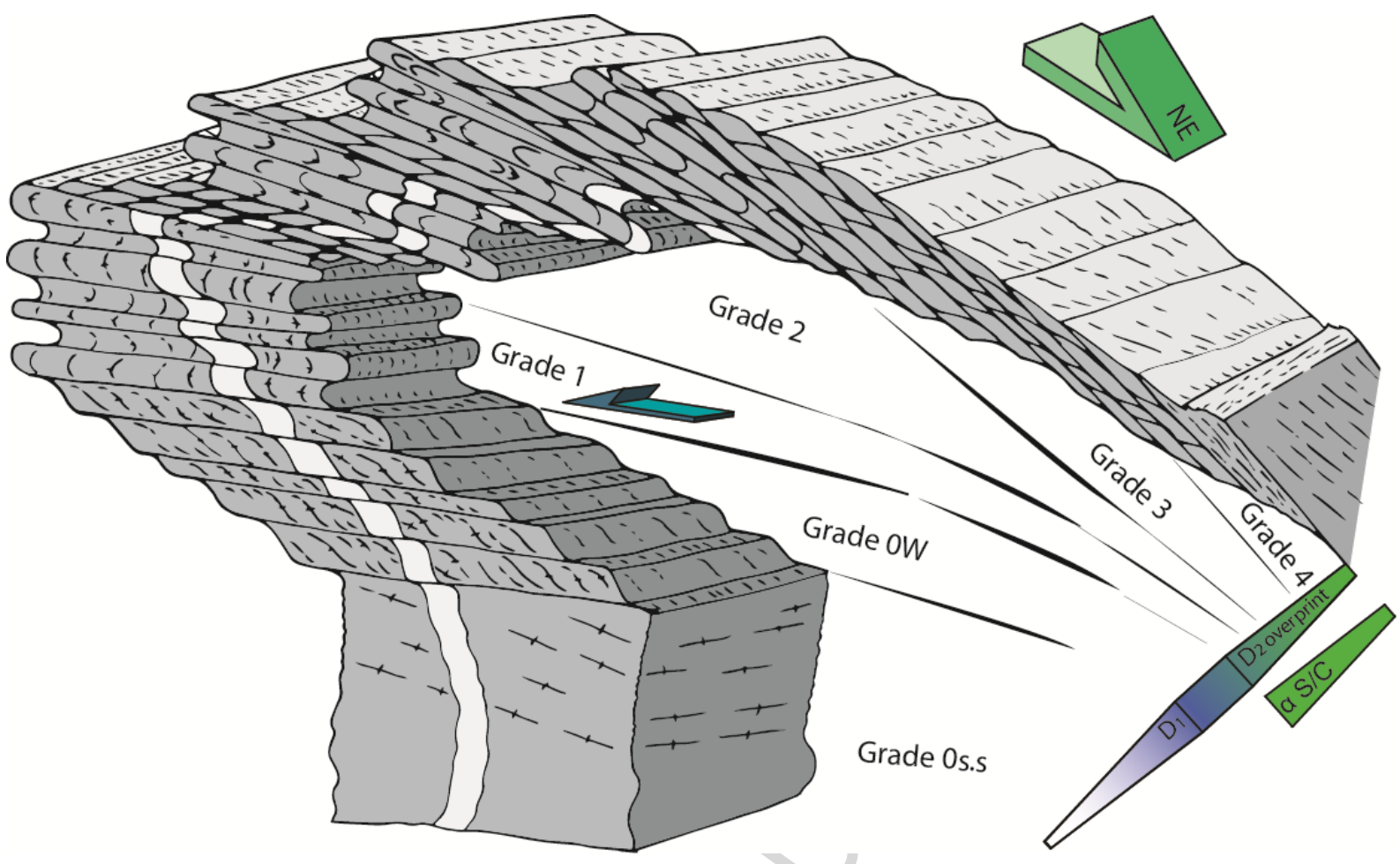

1414

1415 Figure 8

1416 


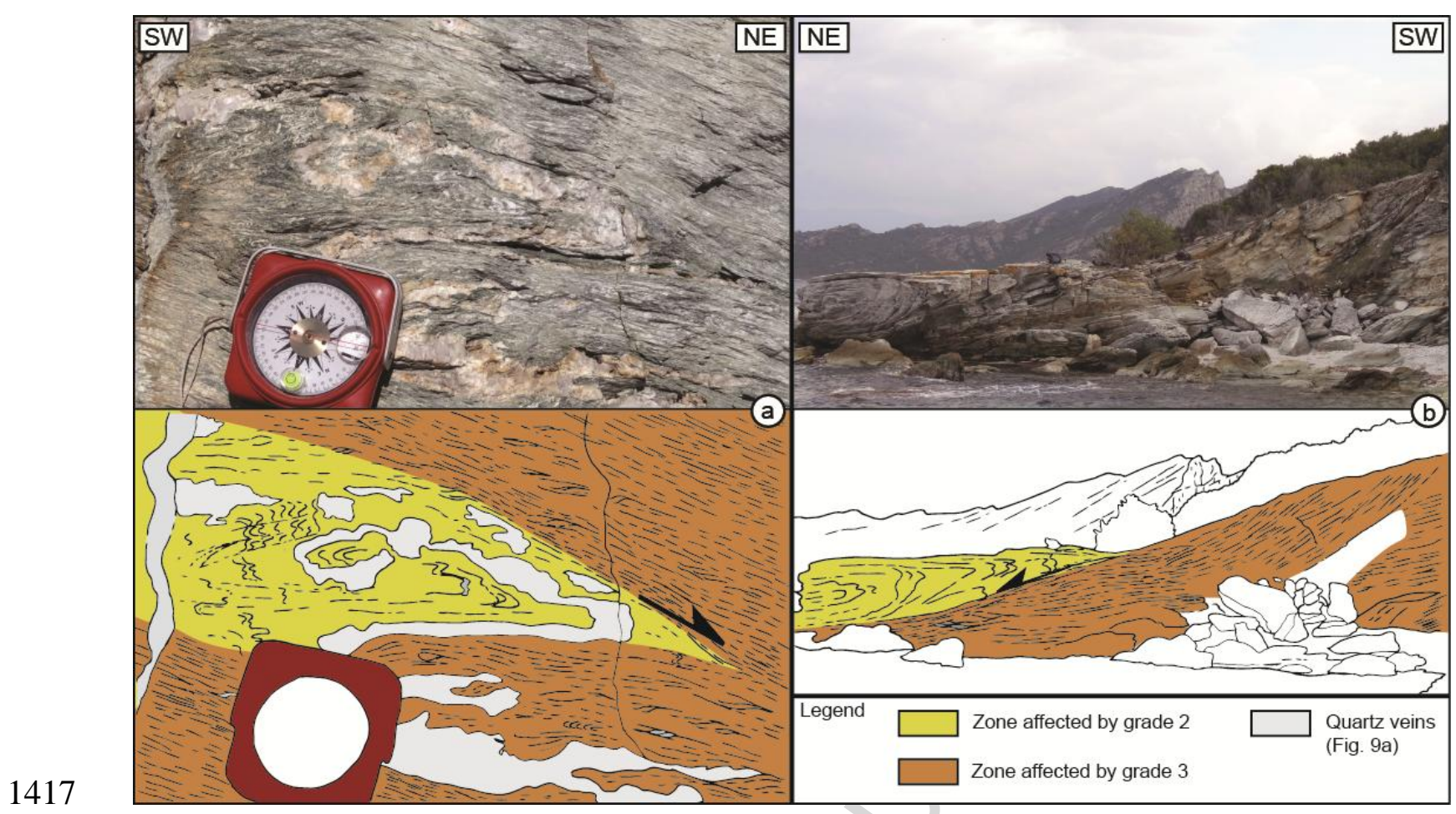

1418

1419 Figure 9

1420 


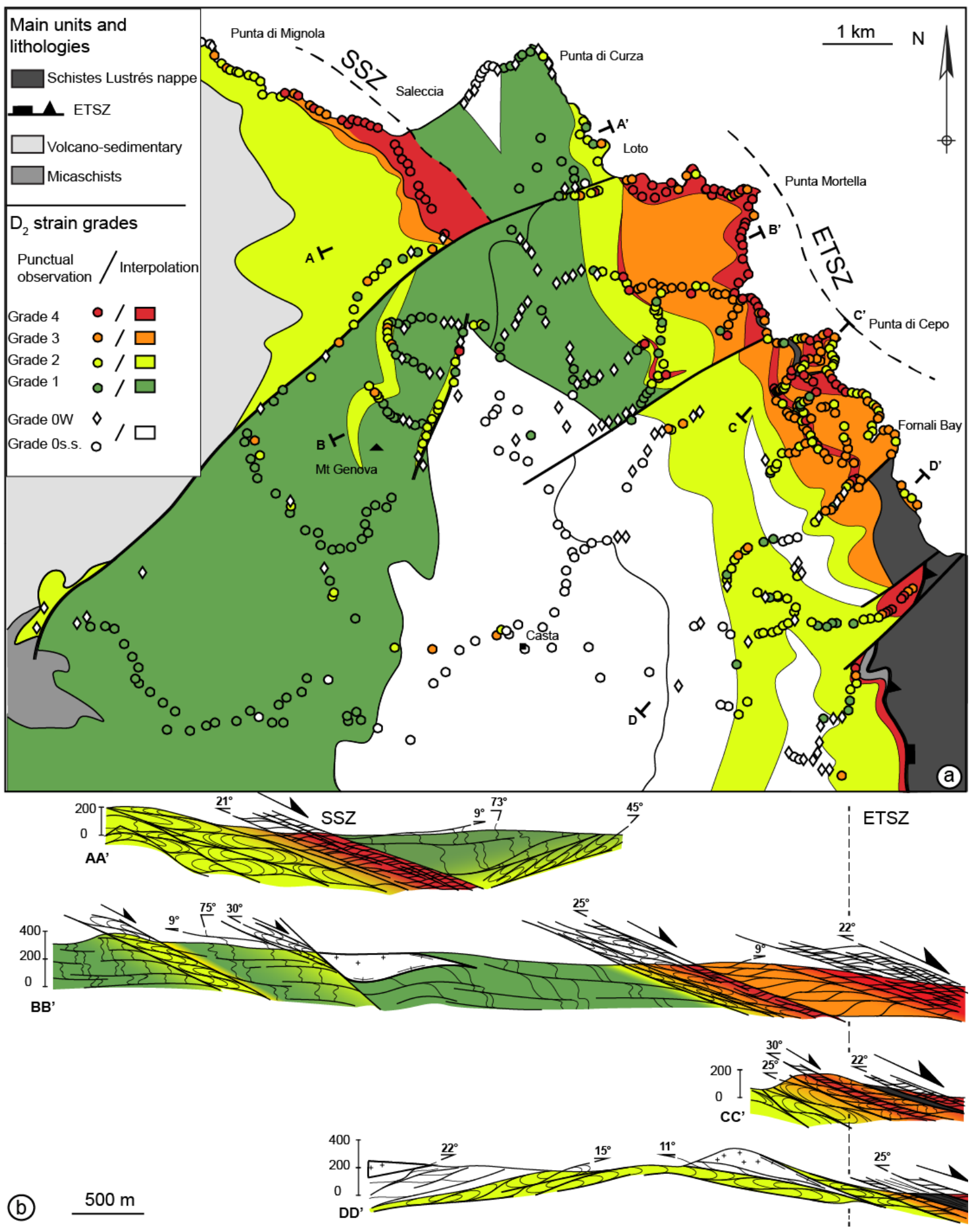

1423 Figure 10 


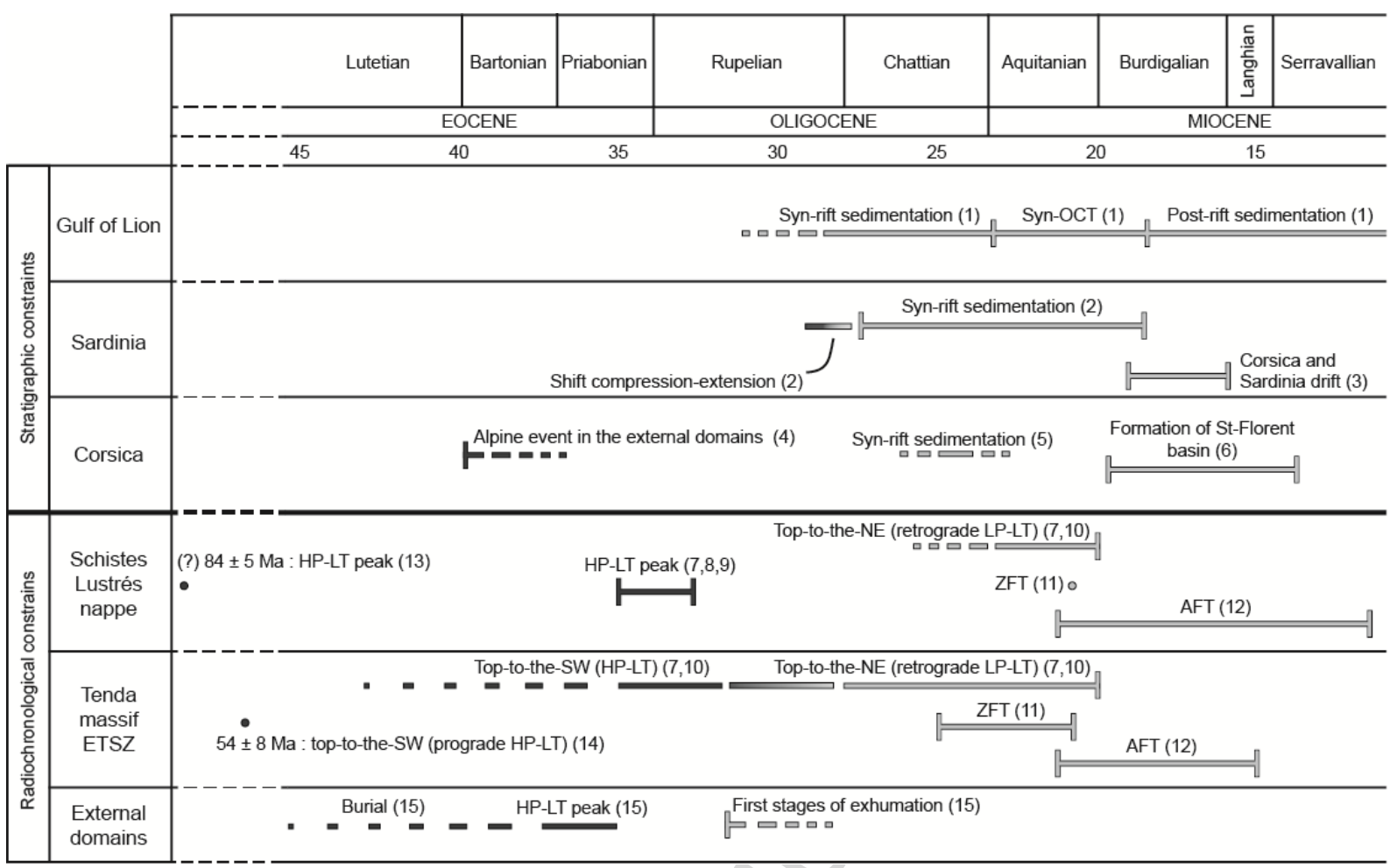

1426

1427 Figure 11

1428 

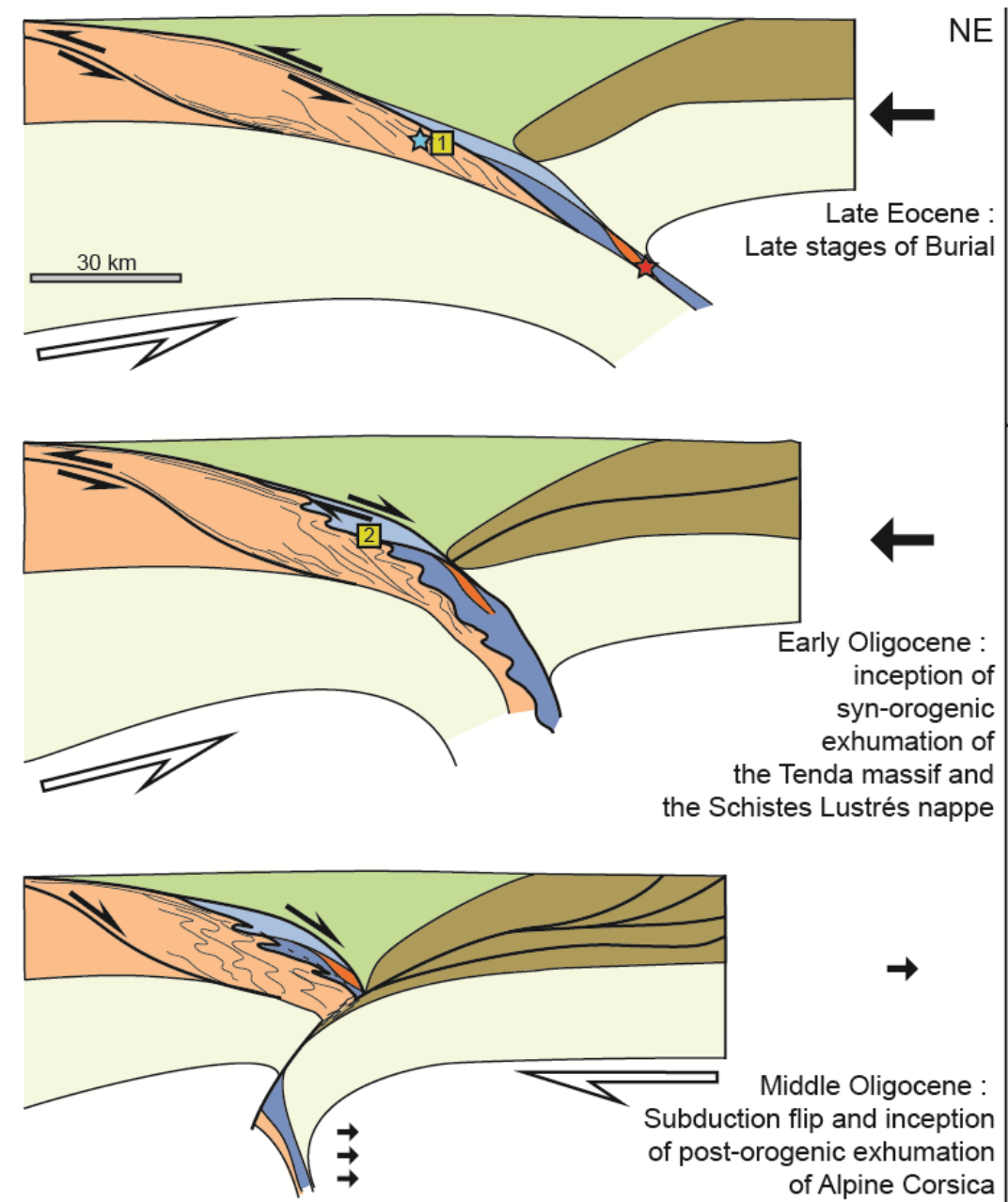
of Alpine Corsica

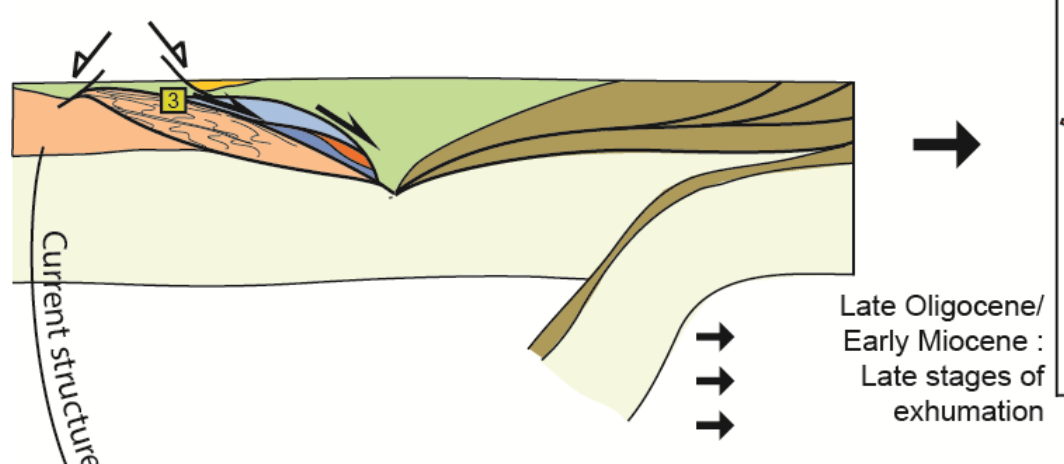

1429

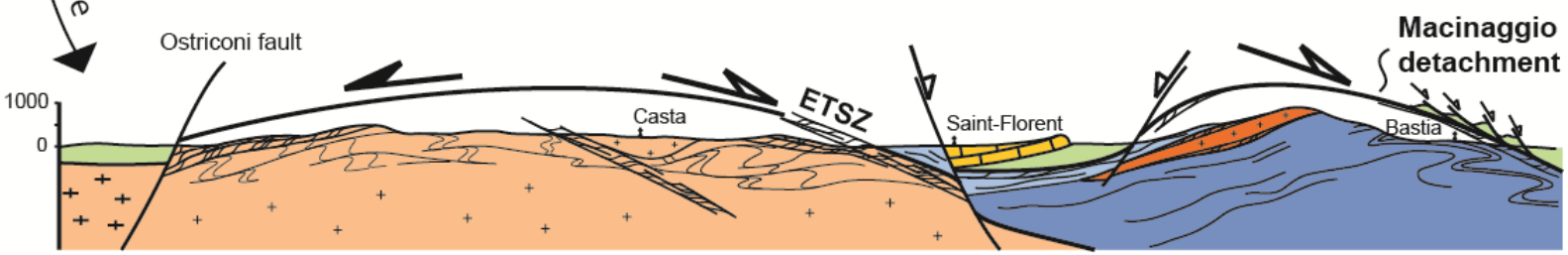




\section{Highlights}

1434 The Tenda massif was not rigid, as deformation was pervasive when exhumation started.

1435 Strain mapping shows a strain localization toward the roof and internal shear zones.

1436 The large-scale finite architecture is a dome of extensional-related structures.

1437 Lithological contacts drive strain localization.

1438 Style of deformation was controlled by protolith nature and P-T-fluids conditions. 